\title{
FOREIGN DEBT DYNAMICS OF THE TURKISH ECONOMY IN THE POST-LIBERALISATION ERA
}

\author{
Aylin SOYDAN*
}

\begin{abstract}
The Turkish economy went through significant changes in the 1980s and onwards following the launch of the January 1980 Programme. The programme aimed for financial liberalisation along with the liberalisation of international trade and this transformation had significant implications for external debt dynamics of the economy. During the 1990s external borrowing accompanied domestic borrowing of the public sector. Total foreign debt of the economy, more specifically, of the private sector, has increased further and reached high levels leading to serious concerns along with high current account deficits and high domestic debt stock of the private sector. This study aims to examine the changing nature and dynamics of the external debt issue in the Turkish economy in the last few decades.
\end{abstract}

Keywords: Foreign debt, Turkish economy, financial liberalisation, international capital flows

JEL Classification: F34, F43, F62, F65

\section{LIBERALIZASYON SONRASI DÖNEMDE TÜRKIYE EKONOMISININ DIŞ BORÇ DINAMIKLERI}

\section{$\ddot{O} z e t$}

Türkiye ekonomisi, 24 Ocak 1980 Programının ilan edilmesinin ardından 1980'li yıllar ve sonrasında önemli değişimler geçirdi. Söz konusu program, uluslararası ticaretin liberalizasyonu yanında finansal liberalizasyonu da amaçlamiştı. Söz konusu dönüşüm sürecinin ekonominin diş borç dinamikleri üzerinde de önemli etkileri oldu. 1990'l y yllarda diş borçlanma süreci kamu kesiminin iç borçlanmasına esslik etti. Ekonominin toplam diş borcu, daha spesifik olarak ise özel sektörün diş borcu, giderek arttı ve yüksek cari açık ve yüksek özel sektör iç borcuyla birlikte ciddi endişelere yol açtı. Bu çalışma, Türkiye ekonomisindeki dış borç sorununun son birkaç onyılda değişen yapısı ve dinamiklerini değerlendirmeyi amaçlamaktadır.

Anahtar Kelimeler: Diş borç, Türkiye ekonomisi, finansal serbestleşme, uluslararasi sermaye akımları

JEL Sinıflaması: F34, F43, F62, F65

* Yrd. Doç. Dr., Okan Üniversitesi, İ̈BF, Tuzla, İstanbul. aylin.soydan@okan.edu.tr 


\section{Introduction}

Prior to the 1980s, developing economies increasingly made use of foreign resources leading to high levels of external debt. Most of the heavily indebted economies experienced severe economic conditions that culminated in debt crises in the late 1970 s or early 1980s, and many of those underwent significant changes through new economic programmes in the 1980s along with the global transformation process.

Turkey had a foreign debt crisis in the late 1970sö and after some stabilisation attempts, a programme designed by the conditions of the IMF and World Bank was launched in January 1980. This was more than a stabilisation programme, aiming for major structural changes and integration with the world economy. The Turkish economy took part in the global transformation process which opened the individual countries to international capital flows as well as free movement of goods and services. The new export-oriented economic model with a focus on financial liberalisation beside free international trade was implemented starting in the $1980 \mathrm{~s}$.

Following a number of steps, liberalisation of capital account in 1989 represented one of the key stages of this transformation process in the Turkish economy. It had implications for the use of foreign resources and dynamics of external borrowing. Although domestic borrowing became the main financing method for public sector deficits from the end of 1980s, external resources were directly or indirectly used for public deficit financing after the full liberalisation in 1989. The rise in external borrowing accompanied domestic borrowing of the public sector, which intensified in the 1990s and early 2000s.

While capital inflows mostly headed towards financial transactions related to the government debt instruments, the private sector borrowed abroad and directed those funds to the same instruments to benefit from high and risk-free returns. Hence, liberalisation process contributed to the growth of private sector's foreign debt, which exceeded the public sector's share after the mid-2000s.

In the post-crisis recovery period, the accumulation of external debt accelerated especially in the 2000s owing to the expansion of international financial funds. Furthermore, the domestic debt stock of the private sector has registered an upsurge since the mid-2000s. The overall performance of the economy has increasingly become dependent on the use of external resources, and on the domestic and foreign borrowing of the private sector.

Despite the continuous increase in the total foreign debt stock, as long as external resources are secured and debt service is maintained, the foreign debt accumulation has not been considered as an urgent problem of the Turkish economy. The debate has been rather focused on the public domestic debt issue, particularly of the 1990s and early 2000s. However, the weight and extent of external borrowing continued rising and external debt stock of the economy has reached critical levels in the past few years along with large current account deficits. More specifically, intensity of private sector's short-term borrowing has led to concerns as the private external debt stock recorded the level of USD 282 billion, which corresponds 35 per cent of GDP as of end-2014. 
This study aims to investigate the changing nature and dynamics of the external debt issue in the Turkish economy in the post-liberalisation context along with the changes in the world economy. The paper is organised as follows. Section 2 gives a brief account of the global transformation process from the 1980s, which sets the ground for the analysis of external debt dynamics of the economy following the financial liberalisation. After reviewing the economic conditions prior to the implementation of the 1980 programme, Section 3 discusses key features of the financial liberalisation and transformation of the Turkish economy in relation with the use of foreign borrowing. Section 4 is devoted to a more detailed examination of the external financing of the economy since the end of the 1980s. Finally, Section 5 draws some conclusions.

\section{Transformation of the World Economy in the 1980s}

The 'golden age' of the world capitalist system in the post-Second World War era witnessed some advancement of the less developed economies as well. During the 1950s and 1960s, the use of external resources was considered essential for development of those economies in the development economics literature as well as in economic policy debates. It was argued that most of the less developed countries did not have sufficient resources that could be directed towards investment, which in turn, was required for economic development. As foreign aid and/or debt was seen almost inevitable for economic development, many less developed countries borrowed increasingly to compensate insufficiency of domestic savings and to meet their foreign currency need for imports of intermediate and capital goods. As a result, the indebtedness of those economies intensified and reached critical levels in the 1970s. This process created serious drawbacks, eventually resulting in foreign debt crises in a number of developing economies at the end of the $1970 \mathrm{~s}$ or in the early $1980 \mathrm{~s}^{1}$

In the meanwhile, following the years of prosperity developed economies started having difficulties owing to declining rate of profits towards the 1970s. Besides, there was a financial expansion mainly stemming from rising petrol prices in the 1970s and this expansion could not be absorbed by the then existing financial markets. Volume and variability of financial instruments were limited, and local and global financial markets were restricted by extensive regulations. Foreign borrowing of developing countries was only a partial solution to the financial expansion of the 1970s. Under these circumstances, in order to compensate the decline in the rate of profits and to absorb financial excess, deregulation of financial markets globally seemed inevitable together with the liberalisation of international trade.

In the new era of financialisation, internationalisation of capital gained mo-

1 While the early work in the related literature focused on the positive aspects of and need for external borrowing, from the 1970s onwards more critical studies that considered negative implications of foreign borrowing for developing economies emerged. In those studies it is argued that most of the external resources are not used for economic development in practice. Moreover, even they are, still they may cause various problems and ruin positive impacts due to payment difficulties, resource transfers, and so on. 
mentum not only in the real sector, but particularly in the financial sphere. ${ }^{2} \mathrm{New}$ financial institutions and instruments emerged, and the volume of financial transactions intensified extremely at a pace that was also accelerated by the communication technologies. Financial markets expanded a few times more than the real sector. Moreover, in order to compensate the decline in the rate of profit from production, industrial corporations also turned their faces to financial areas.

The global economic and financial transformation involved developing countries through the implementation of new economic programmes in the 1980s and onwards, and had significant impact on those economies. It was not a coincidence that a number of developing economies including Turkey got into the financial liberalisation path. In most of the cases, the economies which experienced severe economic conditions accompanied by foreign debt crises were imposed to implement economic programmes comprising liberalisation of financial markets and international trade in the $1980 \mathrm{~s}$.

Most of those economies had a repressed financial regime prior to the $1980 \mathrm{~s}^{3}$ According to the financial liberalisation thesis, as a result of liberalisation of financial markets, free interest rates and free flow of financial resources would stimulate economic development and growth by directing funds towards investments thanks to increased savings, and would also help efficient allocation of resources to the more productive areas. ${ }^{4}$ However, in most of the cases the results did not appear as the theory suggested; savings did not increase as much as expected and additional savings targeted for unproductive speculative areas to a large extent. ${ }^{5}$

Liberalisation of financial markets became a global phenomenon, and constituted one critical feature of the transformation process. However, integration of developing economies with the world economy through liberalisation brought serious

2 For the discussion on 'financialisation' and related issues, see e.g. Gerald A. Epstein (ed.), Financialization and the World Economy. Cheltenham, Massachusetts, Edward Elgar, 2005; Greta Krippner. "The Financialization of the American Economy", Socio-Economic Review, 3, 2005, pp.173-208; J. Bellamy Foster, "The Financialization of Capitalism", Monthly Review, 58(11), 2007; Jonathan Goldstein, "Introduction: The Political Economy of Financialization", Review of Radical Political Economics, 41(4), 2009, pp. 453-457; Palley, Thomas I. "Financialization: What It Is and Why It Matters", The Levy Economics Institute Working Paper, No.525, 2007.

3 Repressed financial system can be characterised by some features such as negative real interest rates, high tax burden on financial savings, highly regulated banking system, high liquidity and required reserve ratios.

4 The financial liberalisation thesis was advanced by the studies of McKinnon and Shaw; see Ronald I. McKinnon, Money and Capital in Economic Development, Washington, DC, The Brookings Institution, 1973 and Edward S. Shaw, Financial Deepening in Economic Development, New York, Oxford University Press, 1973.

5 Liberalisation attempts of developing countries in the 1980s were discussed by a number of studies on the financial liberalisation and economic development relationship. There is also a substantial critical literature on financial liberalisation and its implications for developing countries. 
weaknesses to those economies, and generated much more complicated, fragile and unstable systems. In search for higher returns, unregulated international capital flows created instabilities due to their short-term and speculative character, and played a role in a number of economic/financial crises. With liberalisation and worldwide integration of financial systems, the nature of dependency on foreign resources, and hence, dynamics of external borrowing changed for most of those economies in the age of financialisation.

\section{Liberalisation and External Borrowing in the Turkish Economy in the Post-1980 Era}

\subsection{Foreign Debt Crisis and Implementation of the January 1980 Programme}

In the 1960s and 1970s the Turkish economy had followed an inward-looking import-substitution industrialisation model for about twenty years, a model which was also accompanied by a repressed financial regime. Contrary to the expectations, the protectionist import-substitution model generated an economic structure that became dependent on imports of foreign intermediate and capital goods to maintain domestic production. Hence, the model raised the need for external resources to finance imports as the level of exports did not expand at a similar pace. Moreover, relatively low oil prices prior to the oil crisis of the 1970s had resulted in some kind of energy dependency. Then, the escalated oil prices in the 1970s brought extra burden for the economy, particularly for the public sector as the oil prices were subsidised.

Successive coalition governments attempted to stabilise the economy and retain economic growth in the 1970s. Economic growth was largely fuelled by the public sector, and resulting public deficits were financed by external resources to a great extent. In the meantime, trade deficits were also mounting, and foreign borrowing provided the main financing for those deficits too. Problems accumulated despite the efforts, economic performance rapidly worsened in the second half of the decade and culminated in a debt crisis in 1977.

The external debt problem seemed to be the foremost drawback for the economic policy between 1974 and 1979. The economic policy was largely based on the management of external borrowing, which had an expensive short-term character. Following the 1977 crisis, immediate debt postponements were necessary to set the ground for the implementation of a new economic model, whereas additional external borrowing would help the economy overcome its resource problems. ${ }^{6}$ Despite the postponements and new borrowing opportunities, net foreign borrowing was in deficit in the 1977-79 period, indicating a net resource transfer from Turkey to abroad.

6 Sinan Sönmez, “Türk İktisat Politikalarındaki 'Çıpa': Dış Borçlanma”, in Ahmet Haşim Köse et.al. (eds), İktisadi Kalkınma, Kriz ve İstikrar: Oktar Türel’e Armağan, İstanbul, İletişim Yayınları, p.319. 
Ad hoc adjustment attempts in 1978-1979 failed to improve macroeconomic situation and Turkey entered the 1980s with severe economic conditions accompanied by serious political and social problems. Under these circumstances, a 'market-oriented' stabilisation programme, formed by the conditions of the IMF and World Bank, was launched on the 24th January 1980. The programme was primarily a response to the external crisis of the 1970s. However, its content was more comprehensive and made it more of a structural adjustment programme proposing major changes for the economy. The programme aimed for liberalisation of international trade with its emphasis on an 'export-led' and 'outward-looking' growth strategy, and introduced first measures accordingly. Towards the integration with the world economy, it also sought external and internal liberalisation of the financial system through institutional changes and introduction of new financial instruments. ${ }^{7}$

Subsequent to the introduction of the 1980 Programme, extension of debt postponements and provision of new external resources were still needed to implement the stabilisation measures and to take further steps towards liberalisation. The launch of the programme helped to secure new resources and achieved further postponements owing to the IMF's approval. ${ }^{8}$ Debt postponements also facilitated financing current account deficits as the pressure stemming from debt service was reduced.

Fiscal indicators started worsening in the late 1980s following the general election despite some reduction in the size of public deficits in the first half of the 1980s. While the public sector was leaving the manufacturing sector, it started spending on large-scale projects in the areas such as telecommunication, energy, and transportation. Extra-budgetary funds and foreign borrowing were used to finance those infrastructure investments.

Despite the increases in exports, the rise in the external debt in the second half of the decade partly stemmed from imports due to the liberalisation of trade in the 1980s. Moreover, after the first couple of years of the programme, previously postponed debt payments were due. Hence, the extraction of foreign resources again became critical towards the end of the 1980s. Maintaining foreign debt service was a sine qua non performance criterion for the new economic model. ${ }^{9}$ Since the functioning of the model depended on debt service without any failure, external financial liberalisation was critical in order to obtain external resources. Some steps towards

7 For the features of the Turkish financial liberalisation experience see e.g. Y1lmaz Akyüz, "Financial System and Policies in Turkey in the 1980s," UNCTAD Working Papers, No.25, 1989; Ercan Uygur, "Liberalisation and Economic Performance in Turkey", UNCTAD Working Papers, No.65, 1993; Erinç Yeldan, "Financial Liberalization and Financial Repression in Turkey: Policy Analysis in a CGE Model with Financial Markets", Journal of Policy Modeling, 19(1), 1997, pp.79-117; Izzettin Önder, "Financial Liberalisation in Turkey,” Seijo University Economics Papers, No.136, 1998; Murat Yülek, Financial Liberalization and the Real Economy: The Turkish Experience, Ankara, Capital Markets Board of Turkey, 1998.

8 Sönmez, ibid. p.320.

9 Sönmez, ibid. p.320. 
external liberalisation had already been taken in 1983 and 1984 with the Decrees no. 28 and 30 respectively, and the process was taken further with a final step in 1989.

\subsection{Financial Liberalisation, Public Domestic Borrowing and Short-term Capital Flows}

Following the debt crises, developing economies found themselves in a position where they had to extract domestic resources, i.e. through monetisation and/or domestic borrowing, to sustain their fiscal policies. ${ }^{10}$ Due to insufficiency of domestic savings in those economies, transfer of internal resources was mostly maintained by interest rate increases and inflation.

In the Turkish economy domestic resources were used at an increasing rate to finance public deficits in the 1980s, and within the composition of those fiscal authorities increasingly relied on bonds and treasury bills compared to the monetisation by direct advances from the central bank. Domestic borrowing of the public sector increased from the second half of the 1980s. ${ }^{11}$

After the economic growth phase of the first few years of the 1980 s, the new programme did not seem to be working well. The economic model showed some signs of sluggishness towards the end of the decade. A range of external and internal factors, including high public sector deficits and insufficiency of domestic savings for financing economic growth, as well as implications of financial globalisation, enforced transition to a new accumulation regime.

The liberalisation of international capital movements in 1989 constituted a milestone for economic policies and external financing of the Turkish economy. This was a critical step to sustain public sector's domestic borrowing through external resources. Following the full liberalisation, high interest rates and appreciation (or low depreciation) of the Turkish lira marked a long period starting from the 1990s. The high interest rate - exchange rate arbitrage in real terms attracted capital inflows, and the size of short-run capital movements in order to benefit from high returns through government instruments intensified. Hence, while the weight of domestic borrowing was expanding among alternative financing methods for public deficits in the 1990s, domestic borrowing was increasingly fed by foreign resources.

Prior to the full liberalisation, one significant move in 1989 comprised restrictions on the short-term advances of the central bank to the treasury. Similarly, the central bank would not open credits to the banking sector either. Under these conditions, constraints on the central bank's operations and the bank's strategy to create money through foreign assets also contributed to the upsurge in foreign borrowing. While the public domestic borrowing and domestic debt stock was on a rising trend in the 1990s, public foreign debt stock followed a rather stable path with the exception of the

10 Erinç Yeldan, "Financial Liberalization and Financial Repression in Turkey: Policy Analysis in a CGE Model with Financial Markets”, Journal of Policy Modeling, 19(1), 1997, pp.79-80.

11 Yeldan, ibid. p.80; Akgül Yılmaz and Y1lmaz, ibid. pp. 58-62. 
1994 crisis (Figure 3.1 and Table 3.1). The domestic debt stock of the public sector exceeded the level of public foreign debt in 1997. In the meanwhile, the government debt instruments with escalating interest rates were adding to public deficits with a growing interest burden on the budget, leading to a vicious circle.

Figure 3.1: Public Debt (\% of GDP)

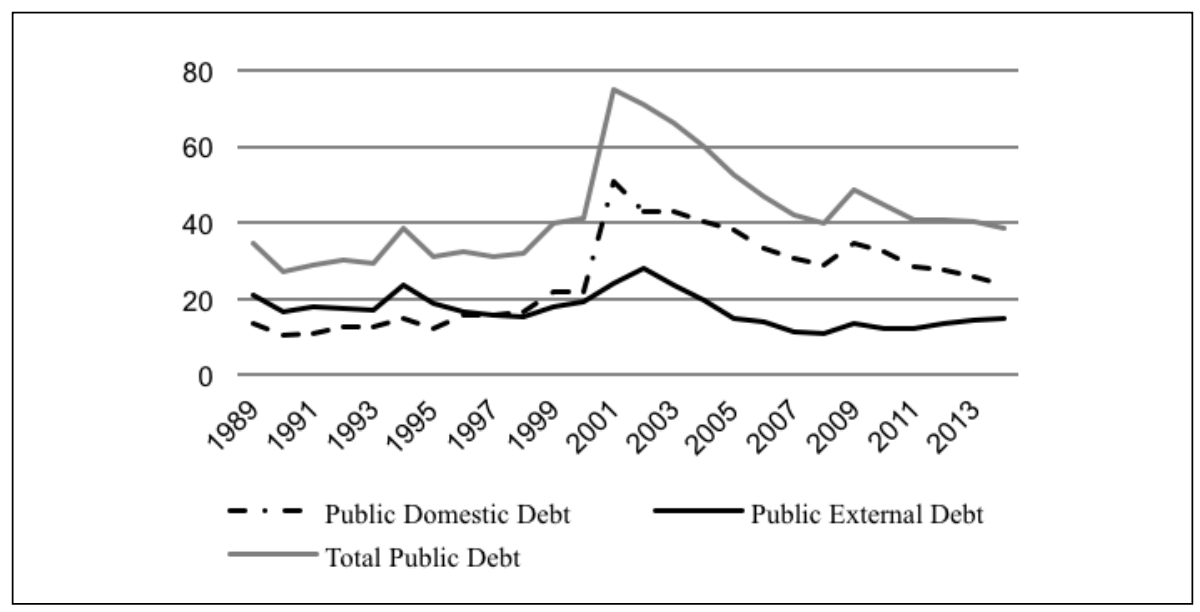

Source: Undersecretariat of Treasury, TurkStat

With the expansion of domestic borrowing, the weight of public sector intensified in rather shallow financial markets in the 1990s. Government debt instruments dominated domestic financial markets with high interest rates, and attracted most of the foreign resources directly or indirectly.

In this setting, commercial banks increasingly moved away from their primary intermediary functions towards trading government debt instruments, which offered stable and risk free net yields. In the earlier years, those instruments were kept as part of banks' liquidity requirements as well as being held as collaterals in the interbank money market. In the 1990 s, more than 80 per cent of the government bonds and bills were being held by the banking system, a process making commercial banks the main financier of fiscal deficits.

The banking system borrowed abroad at lower interest rates and used these resources to lend the public sector with significant real returns of arbitrage. As indicated by the share of government instruments in their balance sheets, public domestic borrowing contributed to high levels of profits of commercial banks. On the other hand, their reliance on short-term borrowing dragged the banking sector into very risky positions stemming from short positions in foreign exchange as experienced in the 1994 and 2001 crises. 
Table 3.1: Public Debt (Million TL, Million USD, \%)

\begin{tabular}{|c|c|c|c|c|c|}
\hline & $\begin{array}{c}\text { Public Domestic } \\
\text { Debt } \\
\text { (Million TL) }\end{array}$ & $\begin{array}{c}\text { Public External } \\
\text { Debt } \\
\text { (Million USD) }\end{array}$ & $\begin{array}{c}\text { Public Domestic } \\
\text { Debt / GDP } \\
\text { (\%) }\end{array}$ & $\begin{array}{c}\text { Public External } \\
\text { Debt / GDP } \\
\text { (\% ) }\end{array}$ & $\begin{array}{c}\text { Total Public } \\
\text { Debt / GDP } \\
\text { (\%) }\end{array}$ \\
\hline 1989 & 42 & 29.446 & 13,5 & 20,6 & 34,1 \\
\hline 1990 & 57 & 33.268 & 10,3 & 16,6 & 26,9 \\
\hline 1991 & 98 & 35.280 & 10,8 & 17,6 & 28,4 \\
\hline 1992 & 194 & 36.476 & 12,5 & 17,3 & 29,8 \\
\hline 1993 & 357 & 39.640 & 12,6 & 16,6 & 29,2 \\
\hline 1994 & 799 & 41.741 & 14,6 & 23,6 & 38,2 \\
\hline 1995 & 1.361 & 42.003 & 12,1 & 18,6 & 30,7 \\
\hline 1996 & 3.149 & 40.192 & 15,5 & 16,5 & 32,0 \\
\hline 1997 & 6.283 & 39.068 & 15,5 & 15,4 & 30,9 \\
\hline 1998 & 11.613 & 41.339 & 16,5 & 15,3 & 31,8 \\
\hline 1999 & 22.920 & 44.107 & 21,9 & 17,8 & 39,7 \\
\hline 2000 & 36.421 & 50.081 & 21,9 & 18,9 & 40,7 \\
\hline 2001 & 122.157 & 47.129 & 50,9 & 24,0 & 74,8 \\
\hline 2002 & 149.870 & 64.533 & 42,8 & 28,0 & 70,8 \\
\hline 2003 & 194.387 & 70.844 & 42,7 & 23,2 & 66,0 \\
\hline 2004 & 224.483 & 75.668 & 40,2 & 19,4 & 59,5 \\
\hline 2005 & 244.782 & 70.411 & 37,7 & 14,6 & 52,3 \\
\hline 2006 & 251.470 & 71.587 & 33,2 & 13,6 & 46,8 \\
\hline 2007 & 255.310 & 73.525 & 30,3 & 11,3 & 41,6 \\
\hline 2008 & 274.827 & 78.306 & 28,9 & 10,6 & 39,5 \\
\hline 2009 & 330.005 & 83.482 & 34,6 & 13,5 & 48,2 \\
\hline 2010 & 352.841 & 89.081 & 32,1 & 12,2 & 44,3 \\
\hline 2011 & 368.778 & 94.238 & 28,4 & 12,2 & 40,6 \\
\hline 2012 & 386.542 & 103.983 & 27,3 & 13,2 & 40,5 \\
\hline 2013 & 403.007 & 115.944 & 25,7 & 14,1 & 39,8 \\
\hline 2014 & 414.649 & 117.697 & 23,7 & 14,7 & 38,4 \\
\hline
\end{tabular}

Source: Based on the data provided by Undersecretariat of Treasury and TurkStat

As seen in Figure 3.1 and Table 3.1, the public external debt as share of GDP decreased to the average of 17 per cent in the 1990s. Then, the 2001 crisis led to a vast upsurge in total public debt, and the domestic debt-to-GDP ratio exceeded the 50 per cent level. It dropped slightly after the crisis and has hovered around 30 per cent since 2003. On the other hand, the domestic debt ratio has never fallen below the pre-crisis level, which was already higher than the average of the 1990s. The impact of the 2001 crisis on the level of public external debt stock was more moderate, i.e. the ratio was around 24 and 28 per cent in 2001 and 2002 respectively, and has settled around 13 per cent on average since the mid-2000s. The fiscal policy approach after the crisis was to achieve certain primary budget surpluses, mainly by contracting public expenditures. Partly owing to the contractionary fiscal policy, domestic borrowing, and hence, public domestic debt accumulation, lost pace after 2004. 


\subsection{Economic Growth Performance After Financial Liberalisation}

It was argued that as a result of financial liberalisation, free interest rates and free flow of financial resources would stimulate economic growth and development in the Turkish economy. Financial liberalisation would help expansion and deepening of financial markets, and direct funds towards investments. However, it did not take place as expected; the level of savings did not increase substantially, and furthermore, domestic savings as well as foreign resources were mostly directed towards speculative areas. As a result, fixed capital investments to the industrial sectors almost stagnated within the economy offering such high rates of return to financial transactions.

Despite some high rates throughout the period, the growth performance of the economy followed an erratic pattern that became dependent on foreign financing provided by capital inflows. ${ }^{12}$ Prior to financial liberalisation, current account deficits stemming from economic growth had led to foreign borrowing. However, after financial liberalisation capital movements became critical to sustain economic growth and led to current account deficits as a result.

Economic growth process was determined by domestic demand and exports. On the other hand, appreciation of the Turkish lira encouraged imports of intermediate and capital goods for domestic production as well as consumption goods. As the production of exports increasingly became dependent on imported components of production, rise in exports was translated into increases in imports.

Capital flows seemed to be detached from goods flows to a great extent, the amount of foreign resources was higher than the amount to finance current account deficits. External resources had more functions than meeting the need for financing current account deficits; used to purchase financial assets and contributed to the accumulation of international reserves at the central bank. Previously, external borrowing was a dependent variable as a financing source, then it turned into an independent variable to the extent it enforced radical changes in the economic structure to maintain foreign debt service. ${ }^{13}$

International flows of financial resources contributed to serious shortcomings of the economy due to their short-term and speculative character. Instability in the economy was confirmed with a number of crises. Pressures originating from the process of integration with the global financial markets and increased external fragility in the financial system had a significant role in those crises to a great extent as well as

12 As Erinc Yeldan argues, the two key characteristics of the growth in the Turkish economy were that; (i) it was mostly fuelled by inflows of hot money, hence, was speculation-led; (ii) it was accompanied by high rates of unemployment; hence, was of the jobless-growth type. In his approach Yeldan refers to the notion of 'speculation-led development' advanced by Grabel. See Erinc Yeldan, "Behind the 2000/2001 Turkish Crisis: Stability, Credibility, and Governance, for Whom?," Bilkent University, mimeo, Ankara, Turkey, 2002 and Ilene Grabel, "Speculation-Led Economic Development: A Post-Keynesian Interpretation of Financial Liberalization Programmes in The Third World", International Review of Applied Economics, 9(2), 1995, pp.127-149.

Sönmez, ibid. p.319. 
internal factors. Typically, a number of IMF-supported stabilisation programmes were put into action following the periods of turmoil. As a result of financial liberalisation, the economy was already left defenceless without any policy options against speculative runs and 'sudden stops'. ${ }^{14}$ These programmes did not intend to make fundamental changes in the economic and financial spheres; mostly focused on reducing uncertainties in the financial markets, stabilising price level and cutting debt stock of the public sector. Dependency on short-term capital flows continued.

The Turkish economy benefited from the excess liquidity in the global financial markets in the post-2001 crisis era and sustained economic growth. While interest rates in the developed economies were low, high arbitrage returns again enabled Turkey to attract huge sums of financial capital with a significant "hot" component. The rise of total external debt stock accelerated after the mid-2000s, and financial expansion was reflected in the private external debt stock. The public external debt followed a more moderate path, and the share of public external debt was exceeded the private sector's after 2005 .

The economy entered the 2008-2009 crisis with serious problems, such as foreign resource- and import-dependent economic growth, high current account deficits, high unemployment, contracted domestic demand, and high foreign debt stock. The total external debt continued climbing and reached the 50 per cent level as of end2014.

\section{External Debt in the Turkish Economy since the 1990s}

As discussed previously, entry of foreign resources to the Turkish economy followed a rising path as the phases of financial liberalisation were completed in the 1980s. The liberalisation of international capital movements in 1989 was a milestone for a new accumulation regime and for the dynamics of external financing.

The growth of foreign debt accelerated by the full liberalisation, moving from the total of USD 44 billion in 1989. The total external debt, in absolute terms as well as share of GDP, indicated an increasing trend during the 1990s, and reached the levels almost 60 per cent of GDP with the impact of the 2001 crisis (Table 4.1, Figures 4.1 and 4.2).

14 For the discussion of those programmes see e.g. Erinç Yeldan, "On the IMF-Directed Disinflation Programme in Turkey: A Program for Stabilisation and Austerity or A Recipe for Impoverishment and Financial Chaos?," in N Balkan (ed) The Ravages of Neo-Liberalism: Economy, Society and Gender in Turkey, New York: Nova Science Publications, 2002, pp.1-28; Yilmaz Akyüz and Korkut Boratav, "The Making of the Turkish Financial Crisis", World Development, 31(9), 2003, pp.1549-1566; ISSA (Independent Social Scientists Alliance). "Turkey in 2005 and Beyond: Macroeconomic Policy, Patterns of Growth and Persistent Fragilities," mimeo, 2005. 
Table 4.1: Term Structure of External Debt by Borrowers (Million USD, \%)

\begin{tabular}{|c|c|c|c|c|c|c|c|c|c|c|c|}
\hline & \multicolumn{3}{|c|}{ Public Sector } & \multicolumn{3}{|c|}{ CBRT } & \multicolumn{3}{|c|}{ Private Sector } & \multirow{2}{*}{$\begin{array}{c}\text { External } \\
\text { Debt }\end{array}$} & \multirow{2}{*}{$\begin{array}{c}\text { Ext } \\
\text { Debt / } \\
\text { GDP }\end{array}$} \\
\hline & $\begin{array}{l}\text { Short } \\
\text { Term }\end{array}$ & $\begin{array}{l}\text { Long } \\
\text { Term } \\
\end{array}$ & Total & $\begin{array}{l}\text { Short } \\
\text { Term } \\
\end{array}$ & $\begin{array}{l}\text { Long } \\
\text { Term } \\
\end{array}$ & Total & $\begin{array}{l}\text { Short } \\
\text { Term } \\
\end{array}$ & $\begin{array}{l}\text { Long } \\
\text { Term } \\
\end{array}$ & Total & & \\
\hline 1989 & 0 & 29.446 & 29.446 & 799 & 7.028 & 7.827 & 4.946 & 1.692 & 6.638 & 43.911 & 30,8 \\
\hline 1990 & 0 & 33.268 & 33.268 & 855 & 7.487 & 8.342 & 8.645 & 2.125 & 10.770 & 52.381 & 26,1 \\
\hline 1991 & 281 & 34.999 & 35.280 & 557 & 6.658 & 7.215 & 8.279 & 2.849 & 11.128 & 53.623 & 26,7 \\
\hline 1992 & 400 & 36.076 & 36.476 & 572 & 6.158 & 6.730 & 11.688 & 3.702 & 15.390 & 58.595 & 27,8 \\
\hline 1993 & 65 & 39.575 & 39.640 & 667 & 6.626 & 7.293 & 17.741 & 5.838 & 23.579 & 70.512 & 29,6 \\
\hline 1994 & 36 & 41.705 & 41.741 & 828 & 8.949 & 9.777 & 10.323 & 6.863 & 17.186 & 68.705 & 38,8 \\
\hline 1995 & 250 & 41.753 & 42.003 & 993 & 11.178 & 12.171 & 14.257 & 7.517 & 21.774 & 75.948 & 33,6 \\
\hline 1996 & 0 & 40.192 & 40.192 & 984 & 11.397 & 12.381 & 16.088 & 10.637 & 26.725 & 79.299 & 32,6 \\
\hline 1997 & 204 & 38.864 & 39.068 & 889 & 10.876 & 11.765 & 16.598 & 16.925 & 33.523 & 84.356 & 33,2 \\
\hline 1998 & 1.602 & 39.737 & 41.339 & 905 & 12.081 & 12.986 & 18.267 & 23.760 & 42.026 & 96.351 & 35,6 \\
\hline 1999 & 1.581 & 42.526 & 44.107 & 686 & 10.320 & 11.006 & 20.654 & 27.357 & 48.011 & 103.123 & 41,7 \\
\hline 2000 & 2.461 & 47.621 & 50.081 & 653 & 13.437 & 14.090 & 25.187 & 29.244 & 54.431 & 118.602 & 44,7 \\
\hline 2001 & 1.019 & 46.110 & 47.129 & 752 & 23.599 & 24.351 & 14.632 & 27.480 & 42.112 & 113.592 & 57,7 \\
\hline 2002 & 915 & 63.618 & 64.533 & 1.655 & 20.348 & 22.003 & 13.854 & 29.202 & 43.056 & 129.592 & 56,2 \\
\hline 2003 & 1.341 & 69.503 & 70.844 & 2.860 & 21.513 & 24.373 & 18.812 & 30.129 & 48.941 & 144.157 & 47,3 \\
\hline 2004 & 1.840 & 73.828 & 75.668 & 3.287 & 18.123 & 21.410 & 27.076 & 36.982 & 64.058 & 161.136 & 41,3 \\
\hline 2005 & 2.133 & 68.278 & 70.411 & 2.763 & 12.662 & 15.425 & 34.018 & 50.883 & 84.901 & 170.737 & 35,5 \\
\hline 2006 & 1.750 & 69.837 & 71.587 & 2.563 & 13.115 & 15.678 & 38.540 & 82.285 & 120.825 & 208.089 & 39,5 \\
\hline 2007 & 2.163 & 71.362 & 73.525 & 2.282 & 13.519 & 15.801 & 38.700 & 122.009 & 160.709 & 250.035 & 38,5 \\
\hline 2008 & 3.248 & 75.058 & 78.306 & 1.874 & 12.192 & 14.066 & 47.397 & 141.157 & 188.554 & 280.926 & 37,9 \\
\hline 2009 & 3.598 & 79.884 & 83.482 & 1.764 & 11.398 & 13.162 & 43.628 & 128.661 & 172.289 & 268.933 & 43,6 \\
\hline 2010 & 4.290 & 84.791 & 89.081 & 1.553 & 10.012 & 11.565 & 71.404 & 119.856 & 191.260 & 291.905 & 39,9 \\
\hline 2011 & 7.013 & 87.225 & 94.238 & 1.239 & 8.095 & 9.334 & 73.344 & 126.986 & 200.330 & 303.902 & 39,3 \\
\hline 2012 & 11.040 & 92.943 & 103.983 & 1.036 & 6.052 & 7.088 & 88.150 & 139.821 & 227.971 & 339.041 & 43,1 \\
\hline 2013 & 17.605 & 98.258 & 115.863 & 833 & 4.401 & 5.234 & 112.051 & 156.392 & 268.443 & 389.540 & 47,4 \\
\hline 2014 & 17.866 & 99.831 & 117.697 & 342 & 2.142 & 2.484 & 114.749 & 167.486 & 282.235 & 402.415 & 50,3 \\
\hline
\end{tabular}

Source : Undersecretariat of Treasury and TurkStat

Although the public foreign debt was generally higher than the private sector's until the mid-2000s (with the exception of the 1998-2000 period), it generally followed a rather moderate course. The 1994 and 2001 crises led to substantial increases in the foreign debt of the public sector. The share of external debt of the CBRT had ups and downs in the 1990s and early 2000s. The CBRT's foreign debt was reasonably low throughout the period except for the 2001-2003 interval, and fell after 2005. The private sector's debt registered a rise in 1999 and 2000, and then showed a slight decline. However, the private sector's external debt exceeded the public sector's in 2005 and continued climbing at a faster pace (Figures 4.1 and 4.2). As indicated by the data in Table 4.1, the total foreign debt increased more than threefold from the 2001 crisis until the end of 2014, whereas the level of private foreign debt rose almost sevenfold in the same period. 
Figure 4.1: External Debt by Borrowers (Million USD)

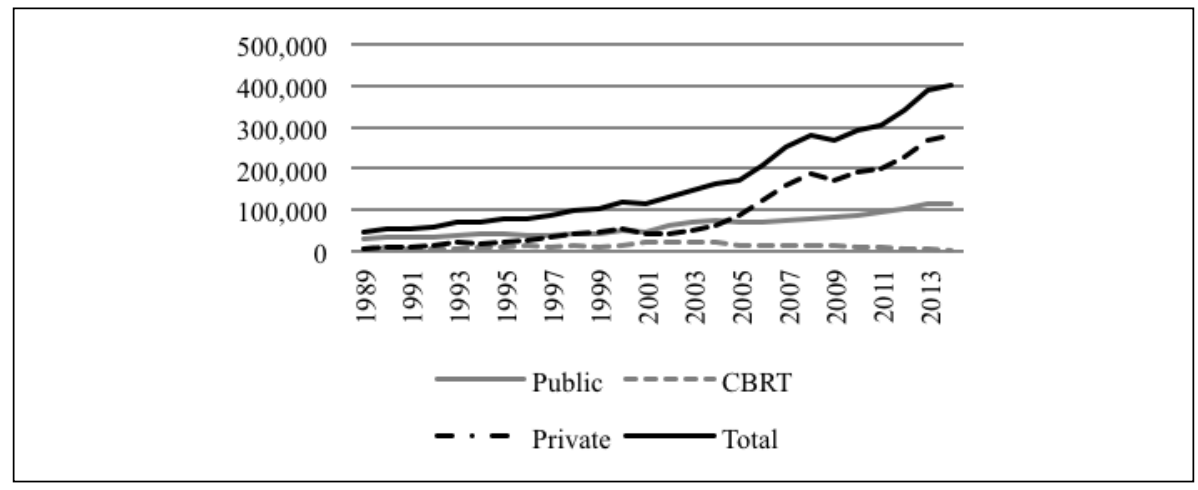

Source: Undersecretariat of Treasury

Figure 4.2: External Debt by Borrowers (\% of GDP)

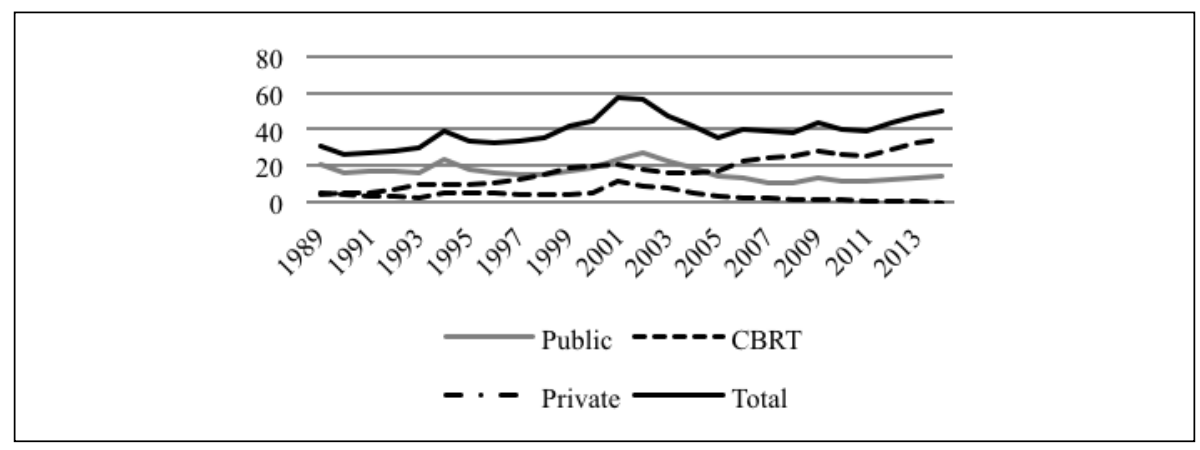

Source: Undersecretariat of Treasury, TurkStat

Expansion of international financial resources in the 2000s fed the rise in the external debt of the Turkish economy, and this process has led to an upsurge particularly in the private sector's share. Turkey attracted international capital also in the form of foreign direct investment. The public sector also benefited from the international capital through privatisation of public enterprises.

The international financial expansion in the 2000s can be observed in the upsurge of private creditors' share in the Turkish foreign debt (Figure 4.3). The level of debt by private creditors indicated a faster rise after 2001. The amount of debt provided by official creditors, which consist of governmental and multilateral organisations, namely the IMF, World Bank, and others, shows a low and stable route throughout the period. The official creditors mostly lent to the public sector for longer term, and the level of official loans rose owing to the 2001 crisis. After 2006 the external debt by official creditors fell and settled around 10 per cent of the total debt. Particularly the IMF debt carried a significant role during the crisis, but dropped after its peak in 2003 
reaching to very low levels in the following years. It is also worth mentioning that short-term debt has been provided almost only by the private creditors except for very limited amount by the official creditors in the last few years.

Figure 4.3: External Debt by Lenders (Million USD)

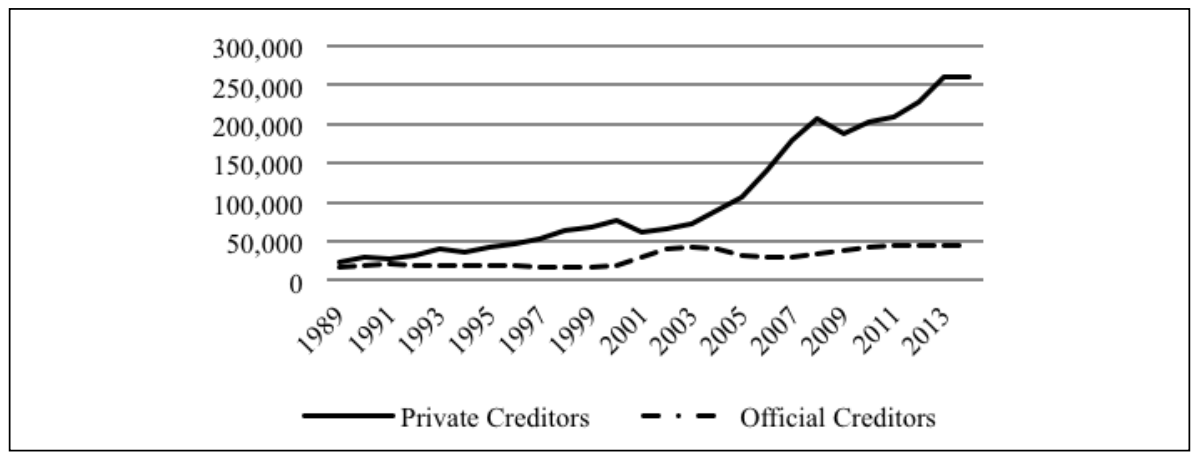

Source: Undersecretariat of Treasury

Figures 4.4 and 4.5 illustrate the term structure of the external debt. Overall, the long-term foreign debt stock indicates higher values throughout the period of our analysis. However, as seen in the figure, the accumulation of the total short-term debt seems to be faster compared to the long-term debt from 2011 and onwards. Furthermore, the data indicate the end-year stock levels, not the volume of total borrowing during any given year. Hence, these values do not reflect the intensity of short-term borrowing in those years, which constituted one significant source of instability in the economy.

Figure 4.4: Total External Debt by Maturity (Million USD)

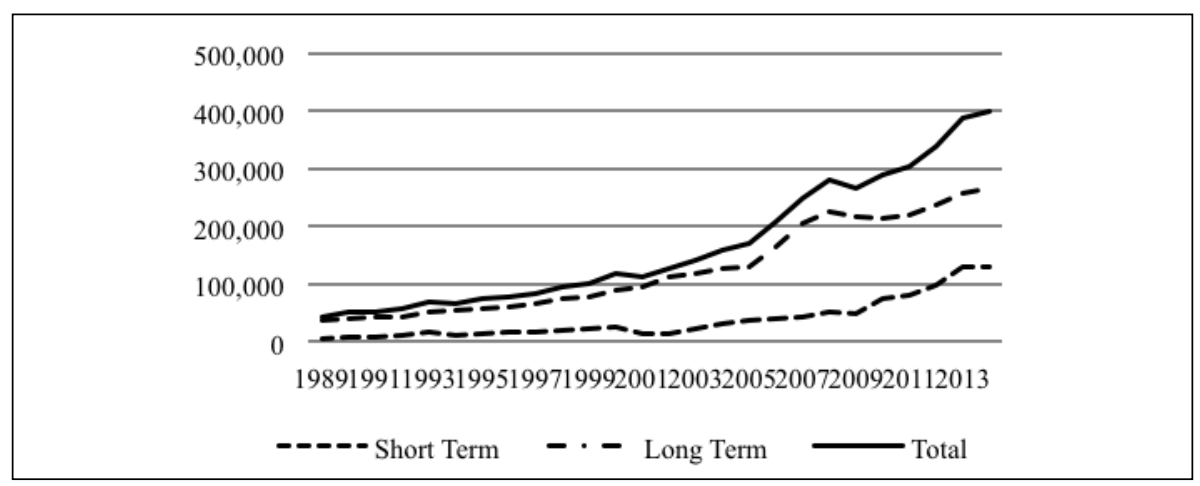

Source: Undersecretariat of Treasury 
Figure 4.5: Total External Debt by Maturity (\% GDP)

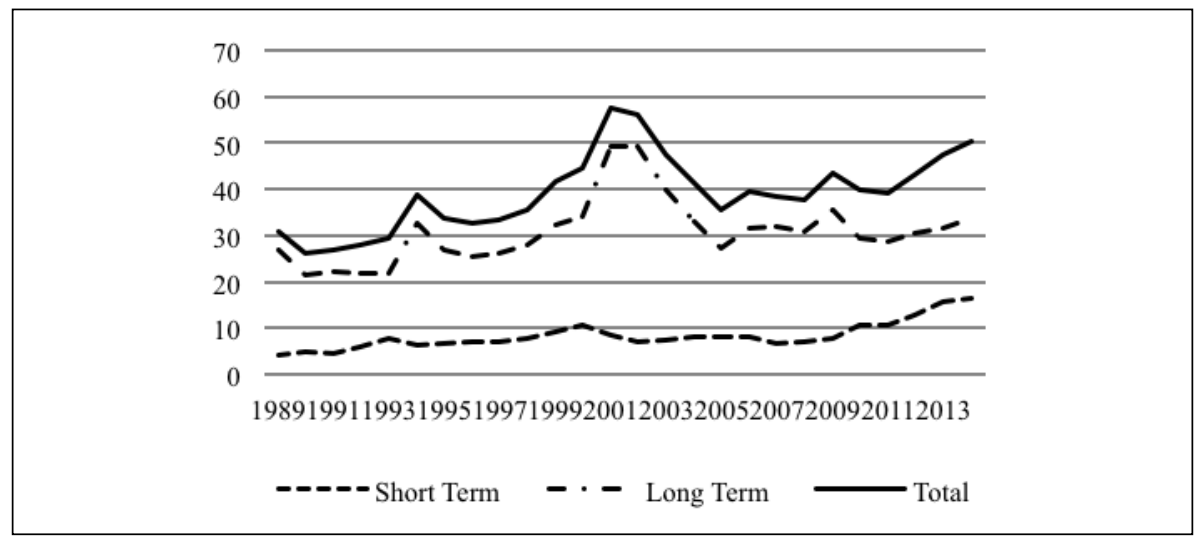

Source: Undersecretariat of Treasury, TurkStat

The short-term foreign debt stock of private sector has always been higher compared to the public sector's (Table 4.1 and Figure 4.6). The difference has widened since the 2000s as the short-term private debt has followed a steeper path, especially after 2009, despite the fast surge also observed in the public sector's short-term foreign debt. The private short-term external debt recorded a growth rate of 728,3 per cent between 2002 and 2014, whereas total external debt expanded by 210,5 per cent in the same period. On the other hand, the public sector's long-term foreign debt was higher than the private sector's for a long time (Table 4.1 and Figure 4.7). The long-term private debt followed an increasing trajectory from the 1990s. It speeded up in the early 2000s and passed the public sector's in 2006, whereas the public sector long-term debt has kept a more moderate trend during the whole period. The longterm private debt declined between 2008 and 2010 owing to the crisis, and mounted afterwards reaching USD 167,5 billion at the end of 2014.

Figure 4.6: Short-Term External Debt by Borrowers (Million USD)

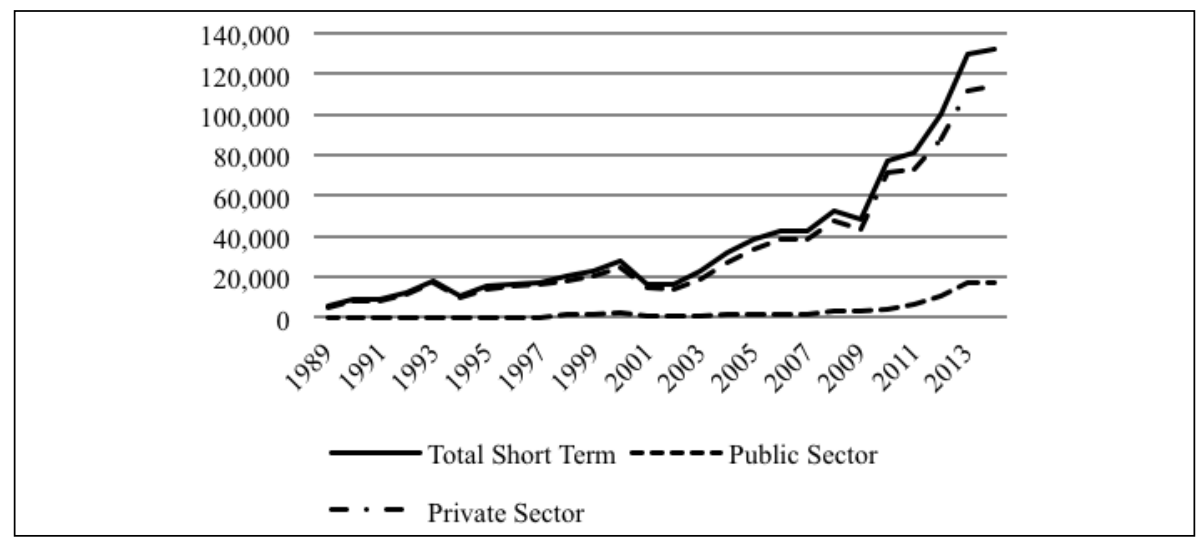

Source: Undersecretariat of Treasury 
Figure 4.7: Long-Term External Debt by Borrowers (Million USD)

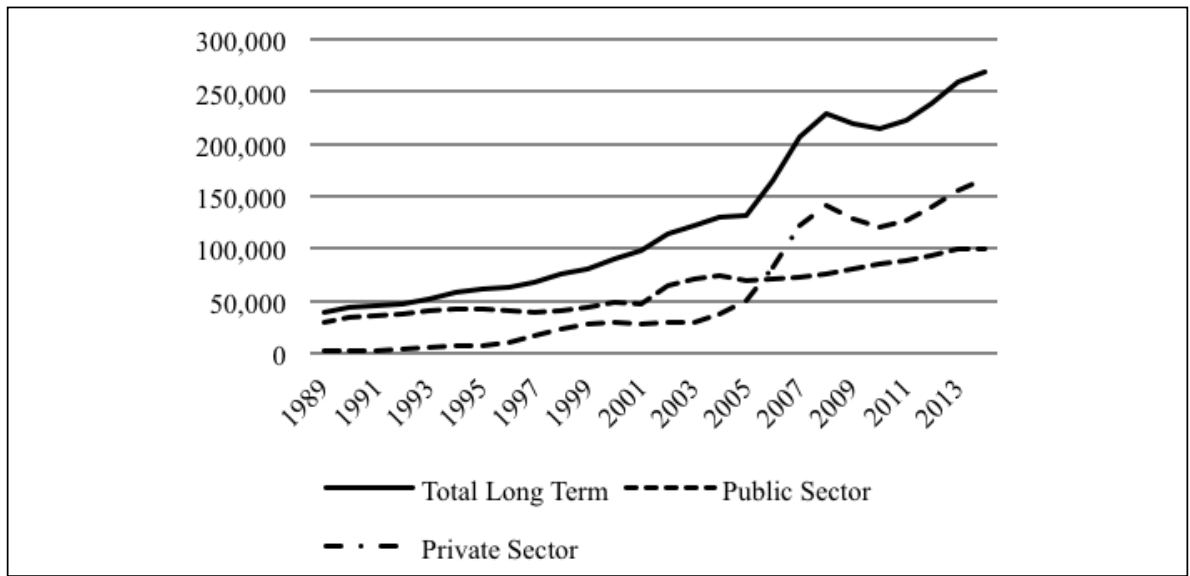

Source: Undersecretariat of Treasury

Maturity structures of the public and private debt as shares of GDP are presented together in Figure 4.7. The ratios seem to have peaks with effect of the crises. As can be seen in the figure, while the long-run public debt as the ratio of GDP is in a decreasing trend after the upswing of the 2001 crisis, it is passed by the long-term private debt ratio in 2006. More interestingly, the short-term private debt ratio exceeds the long-run public debt ratio in 2012. Even there exists a decline in the debt stock during a crisis, the debt-to-GDP ratio can indicate a peak due to the level of decrease in GDP. Therefore, although the long-term public external debt indicated a modest route as presented in Figure 4.7, the long-term public debt-to-GDP ratio had a rather erratic pattern throughout the period mainly due to the fluctuations in GDP (Figure 4.8).

Figure 4.8: Term Structure of External Debt by Borrowers (\% of GDP)

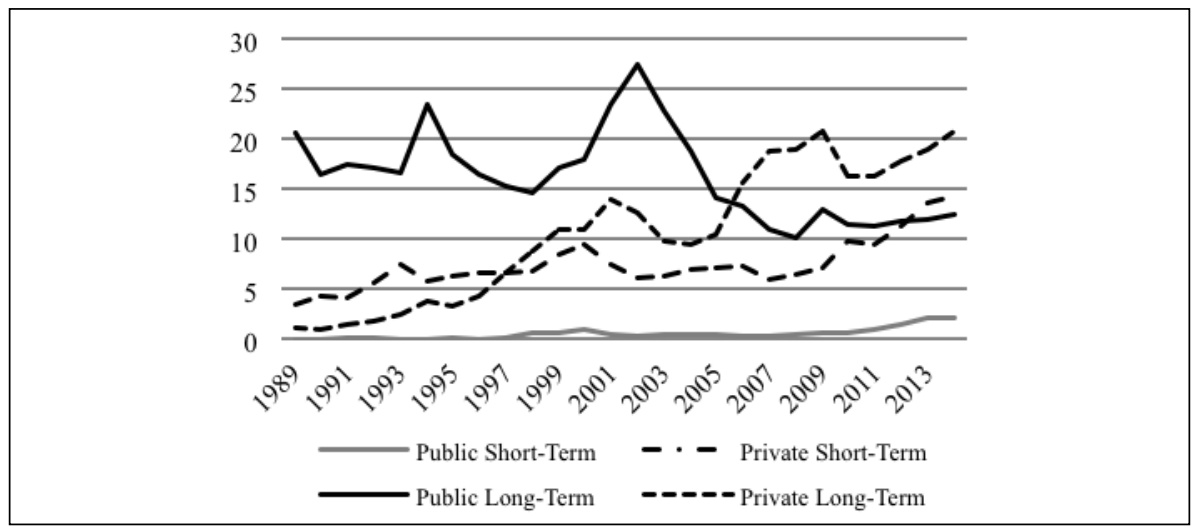

Source: Undersecretariat of Treasury, TurkStat 
As discussed earlier, economic and financial conditions of the 1990s and early 2000s were mostly influenced by large public deficits and public borrowing. In these circumstances, a big portion of private external borrowing was indirectly determined by domestic borrowing of the public sector. The short-term external debt stock of the private sector was higher than its long-term debt until 1997 (Figure 4.9). Then the long-term private debt exceeded the short-term component, and accelerated after 2004, reaching high levels just before the 2008 crisis. As indicated by the slope of the line, growth of the short-term private debt was more moderate until the 2008-2009 crisis, but it showed a steeper trend afterwards (Figure 4.9)

Figure 4.9: Term Structure of Private External Debt (Million USD)

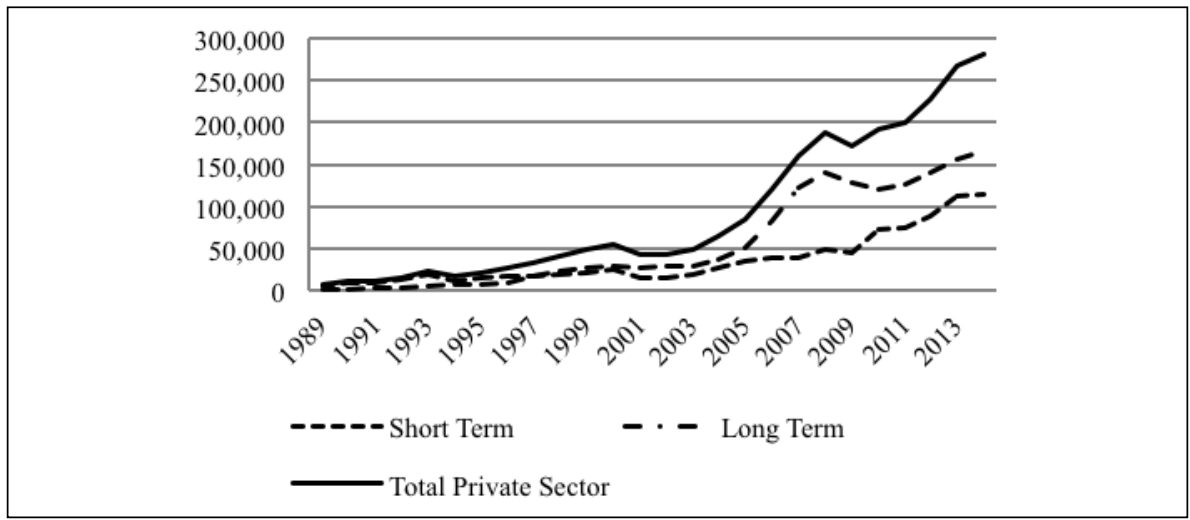

Source: Undersecretariat of Treasury

\subsection{Developments in the Composition of Private External Debt}

The private sector's external debt both in absolute terms and as share of GDP has generally had an increasing trend with a number of short periods of decline since the end of 1980s. Within the private external debt, financial institutions, mainly the banking sector, had the larger share in total debt until the first half of the 1990s (Table 4.2, Figures 4.10 and 4.11). In order to get involved with public domestic borrowing, commercial banks used foreign resources, and hence, the rise in private foreign debt was mainly caused by the financial institutions' borrowing until the mid-1990s. On the other hand, non-financial private sector also borrowed from abroad at lower interest rates, and used those funds in financial transacitons as well as production-related needs. Following the 1994 crisis, non-financial institutions' foreign debt share exceeded financial institutions'. The share of non-financial private sector in foreign debt continued increasing in the post-crisis era, reached its peak in 2000, slowed down in the first half of the 2000s, and then again speeded up prior to the 2008 crisis.

With the impact of the crisis, the foreign debt of non-financial institutions seemed to have slowed down, whereas the financial institutions increased the level of external borrowing adding to their debt stock (Figures 4.10 and 4.11, and Table 4.2). The share of financial institutions in total external debt exceeded the non-financial institutions' in 2012 again. 
Figure 4.10: Private Debt : Financial and Non-Financial Institutions (\% of Total)

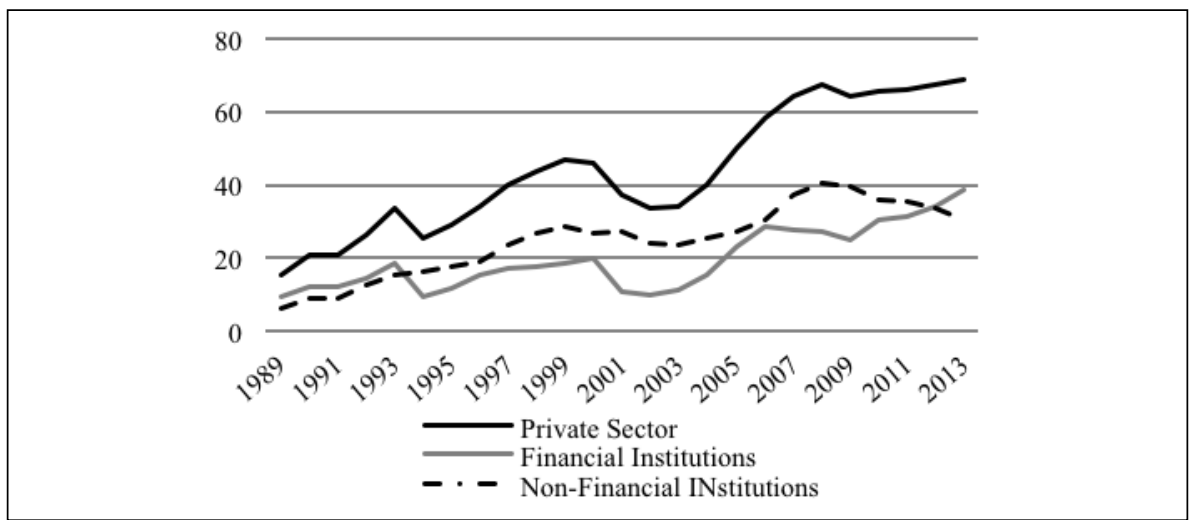

Source: Undersecretariat of Treasury

Figure 4.11: Private Debt: Financial and Non-Financial Institutions (\% of GDP)

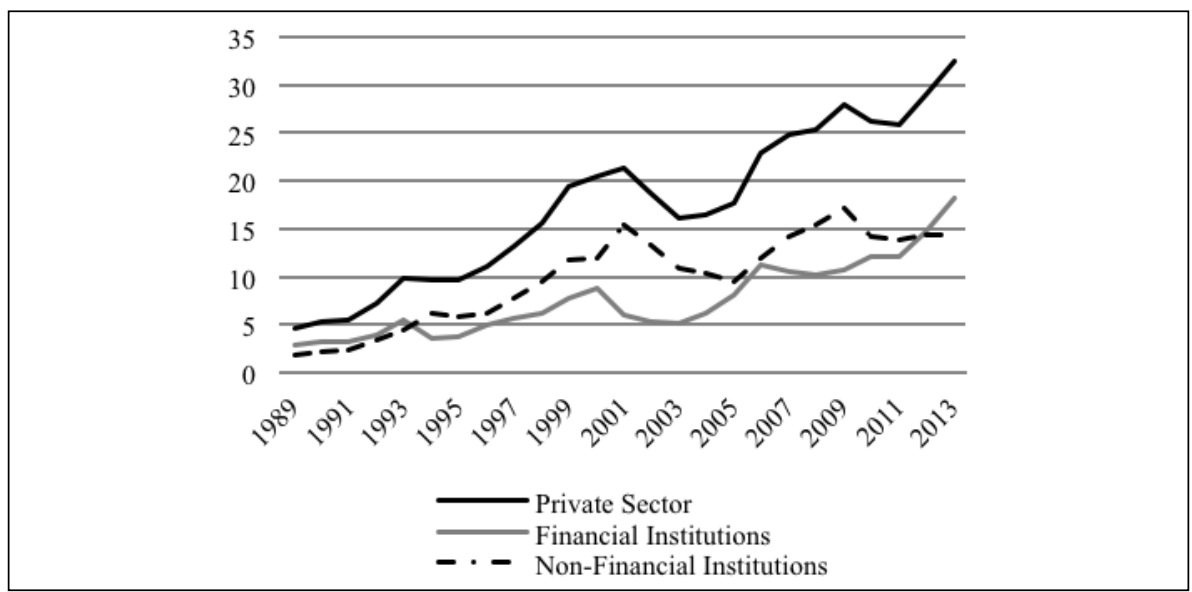

Source: Undersecretariat of Treasury, TurkStat 


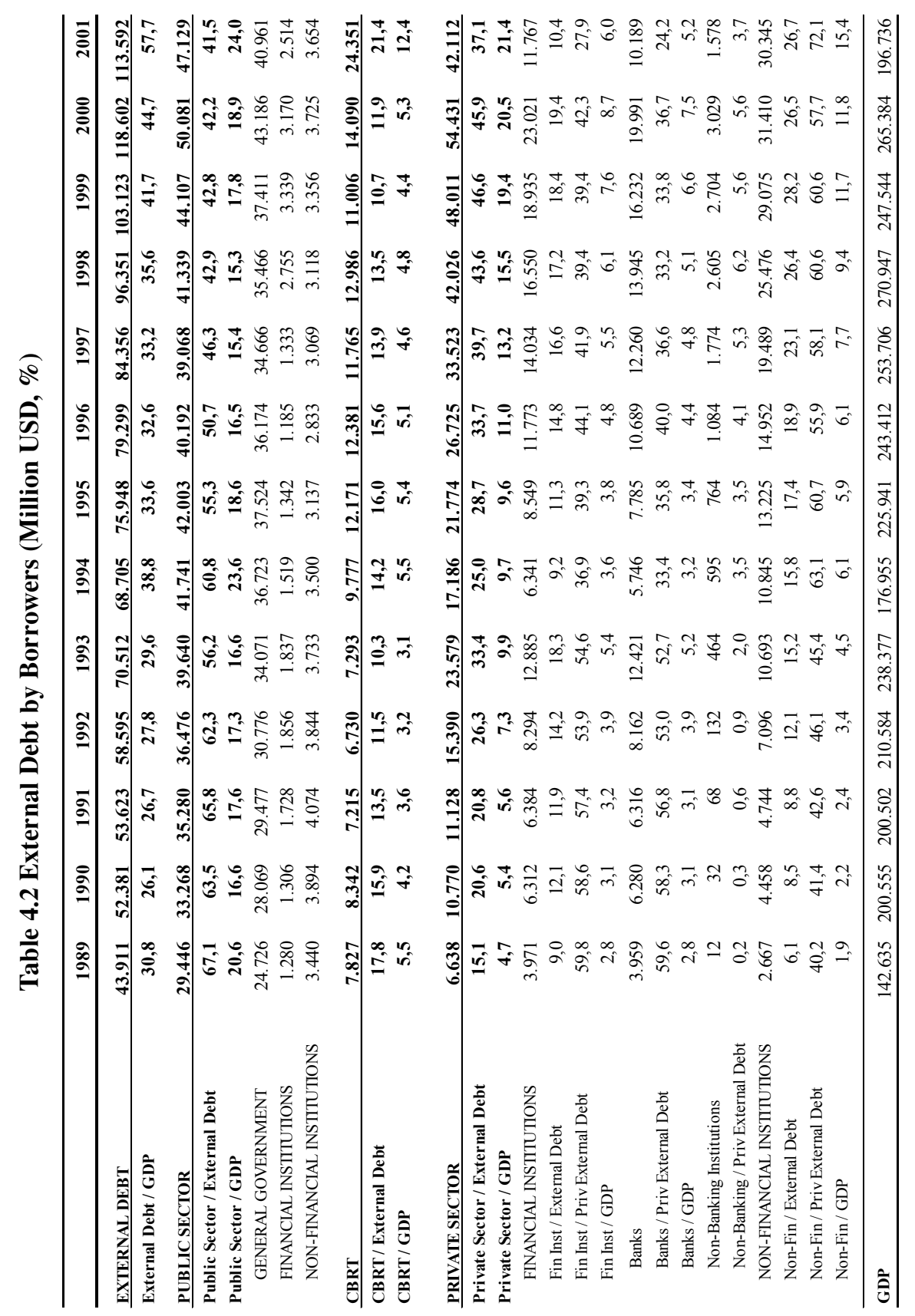




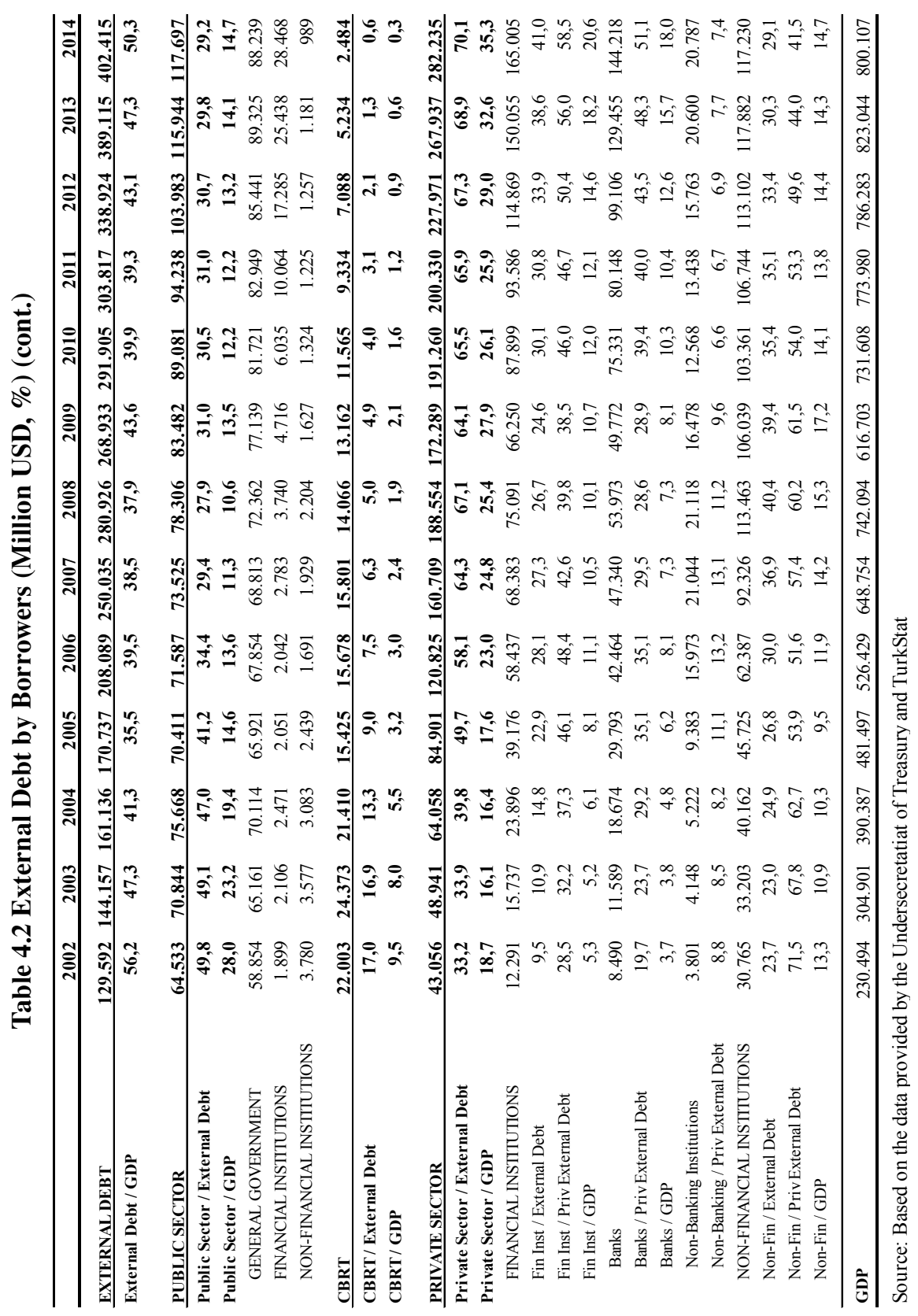


One reason for the concerns regarding the private sector's external debt stems from the level of their foreign exchange liabilities of the non-financial institutions compared to their foreign exchange assets. Net foreign exchange position may carry significant exchange rate risks with the possibility of depreciation of local currency especially when reaches high levels. In the post-2001 crisis era, while the private sector's external debt was escalating, non-financial institutions' financial positions worsened. The net foreign exchange position of the Turkish non-financial companies was USD -6,5 billion in 2002 whereas it recorded the level around USD -178,4 billion as of end 2014, leading to serious distress (Table 4.3). The foreign exchange position, stemming from USD 280,4 billion worth of liabilities against USD 102,0 billion foreign assets, constitutes one of the weaknesses of the private sector.

\section{Table 4.3: Foreign Exchange Positions of Non-financial Institutions} (Million USD, \%)

\begin{tabular}{|c|c|c|c|c|c|c|c|c|c|}
\hline & 2002 & 2007 & 2008 & 2009 & 2010 & 2011 & 2012 & 2013 & 2014 \\
\hline ASSETS & 25.100 & 76.132 & 80.465 & 80.385 & 87.379 & 82.183 & 89.402 & 94.060 & 102.003 \\
\hline Deposits & 16.678 & 54.821 & 60.370 & 57.301 & 62.150 & 54.755 & 61.298 & 63.872 & 67.340 \\
\hline Securities & 146 & 831 & 695 & 1.116 & 1.288 & 929 & 843 & 349 & 277 \\
\hline Export Receivables & 3.471 & 10.289 & 8.566 & 9.310 & 10.526 & 10.945 & 11.693 & 13.175 & 12.167 \\
\hline Direct Investment Abroad & 4.805 & 10.191 & 10.834 & 12.658 & 13.415 & 15.554 & 15.568 & 16.664 & 22.219 \\
\hline LIABILITIES & 31.638 & 129.705 & 151.068 & 147.165 & 176.298 & 200.245 & 224.896 & 264.089 & 280.380 \\
\hline Loans & 26.293 & 115.214 & 136.442 & 131.923 & 158.198 & 179.804 & 202.396 & 235.925 & 252.313 \\
\hline Domestic Loans & 600 & 46.323 & 48.066 & 50.333 & 81.887 & 102.292 & 121.842 & 155.164 & 171.705 \\
\hline Domestic Loans/Liabilities & 1,9 & 35,7 & 31,8 & 34,2 & 46,4 & 51,1 & 54,2 & 58,8 & 61,2 \\
\hline Banks & 0 & 32.805 & 37.435 & 41.155 & 73.015 & 92.608 & 111.158 & 144.041 & 160.099 \\
\hline FX Loans & 0 & 20.800 & 22.547 & 28.897 & 57.268 & 74.522 & 90.209 & 116.762 & 133.748 \\
\hline FX Indexed Loans & 0 & 12.005 & 14.888 & 12.258 & 15.747 & 18.086 & 20.949 & 27.279 & 26.351 \\
\hline Non-Bank Financial Instit. & 0 & 8.220 & 8.576 & 7.320 & 6.739 & 7.312 & 8.293 & 9.709 & 10.223 \\
\hline Loans Taken Over by SDIF & 600 & 5.298 & 2.055 & 1.858 & 2.133 & 2.372 & 2.391 & 1.414 & 1.383 \\
\hline External Loans & 25.693 & 68.891 & 88.376 & 81.590 & 76.311 & 77.512 & 80.554 & 80.761 & 80.608 \\
\hline External Loans/Liabilities & 81,2 & 53,1 & 58,5 & 55,4 & 43,3 & 38,7 & 35,8 & 30,6 & 28,7 \\
\hline Import Payables & 5.345 & 14.491 & 14.626 & 15.242 & 18.100 & 20.441 & 22.500 & 28.164 & 28.067 \\
\hline Net Foreign Exchange Position & -6.538 & -53.573 & -70.603 & -66.780 & -88.919 & -118.062 & -135.494 & -170.029 & -178.377 \\
\hline
\end{tabular}

Source: CBRT

One other concern regarding the private sector's external debt relates to the use of foreign resources. Table 4.4 provides the data on the sectoral composition of the long-term private external debt. In the period between 2002 and 2014 the non-financial private sector's long-term external debt seems to have a higher share compared to the financial sector's with the exception of 2014. More importantly, within the non-financial sector, the amount of external debt used by services has been more than the industrial sectors which are expected to contribute to the productive capacity of the economy more directly. For instance, the construction sector has much higher external debt stock than each of the manufacturing sectors. In 2014 the level of long-term external debt of manufacturing seems to be lower than the previous two years', and almost half of the long-term external debt of the services. 
Table 4.4: Sectoral Composition of the Long-Term Private External Debt

\begin{tabular}{|c|c|c|c|c|c|c|c|c|c|}
\hline & 2002 & 2007 & 2008 & 2009 & 2010 & 2011 & 2012 & 2013 & 2014 \\
\hline TOTAL & 29.206 & 121.986 & 141.160 & 128.636 & 119.953 & 126.969 & 139.792 & 155.913 & 167.685 \\
\hline I- FINANCIAL & 6.895 & 52.155 & 51.836 & 45.278 & 41.295 & 48.074 & 57.094 & 73.097 & 85.007 \\
\hline Banks & 3.065 & 31.161 & 30.284 & 28.191 & 28.746 & 34.912 & 41.752 & 54.900 & 65.979 \\
\hline Non-bank financial institutions & 3.830 & 20.994 & 21.552 & 17.087 & 12.549 & 13.162 & 15.342 & 18.197 & 19.028 \\
\hline II- NONFINANCIAL & 22.311 & 69.831 & 89.324 & 83.358 & 78.658 & 78.895 & 82.698 & 82.817 & 82.677 \\
\hline AGRICULTURE & 85 & 275 & 434 & 473 & 627 & 618 & 609 & 508 & 441 \\
\hline INDUSTRIAL SECTORS & 13.080 & 31.467 & 40.304 & 37.906 & 36.044 & 35.462 & 37.831 & 37.450 & 35.826 \\
\hline Mining and Quarrying & 437 & 3.062 & 4.047 & 3.833 & 3.620 & 2.969 & 2.704 & 2.119 & 2.373 \\
\hline Manufacturing & 7.760 & 23.847 & 28.149 & 24.912 & 22.930 & 22.942 & 24.997 & 25.151 & 23.896 \\
\hline Food Products, Beverages and Tobacco & 1.170 & 3.862 & 6.302 & 5.686 & 4.729 & 4.466 & 4.746 & 5.156 & 4.491 \\
\hline Textiles and Textile Products & 1.159 & 3.315 & 3.401 & 2.880 & 2.983 & 3.310 & 3.110 & 2.747 & 2.658 \\
\hline Leather and Leather Products & 10 & 57 & 74 & 59 & 82 & 101 & 127 & 100 & 103 \\
\hline Wood and Wood Products & 53 & 594 & 604 & 290 & 243 & 209 & 318 & 446 & 421 \\
\hline Pulp, Paper, Paper Products, Pub. and Printing & 474 & 1.103 & 1.092 & 820 & 746 & 653 & 628 & 585 & 515 \\
\hline Coke, Refined Petrol'm Products, Nuclear Fuel & 293 & 395 & 296 & 462 & 546 & 621 & 1.336 & 1.238 & 1.262 \\
\hline Chemicals, Chemical Products, Basic Pharmac. & 1.041 & 1.998 & 2.320 & 2.025 & 1.779 & 1.878 & 2.546 & 1.944 & 1.835 \\
\hline Rubber and Plastic Products & 150 & 870 & 1.096 & 951 & 958 & 941 & 973 & 939 & 1.050 \\
\hline Other Non-Metallic Mineral Products & 196 & 1.760 & 2.061 & 1.922 & 1.537 & 1.292 & 1.007 & 1.155 & 1.010 \\
\hline Basic Metals and Fabricated Metal Products & 1.125 & 4.152 & 4.788 & 4.476 & 4.387 & 4.360 & 4.047 & 3.712 & 3.292 \\
\hline Machinery and Equipment n.e.c. & 171 & 1.357 & 1.512 & 1.017 & 764 & 534 & 506 & 296 & 277 \\
\hline Computers, Electronic-Electrical and Optical Eq. & 724 & 1.586 & 1.371 & 1.352 & 1.503 & 2.050 & 2.567 & 3.204 & 3.141 \\
\hline Transport Equipment & 1.159 & 2.469 & 2.903 & 2.741 & 2.482 & 2.321 & 2.755 & 3.135 & 3.077 \\
\hline Manufacturing n.e.c. & 34 & 328 & 330 & 230 & 191 & 206 & 332 & 493 & 763 \\
\hline Electricity, Gas, Steam and Air-conditioning & 4.223 & 4.234 & 7.880 & 9.010 & 9.432 & 9.548 & 10.125 & 10.173 & 9.542 \\
\hline Water Supply; Sewerage, Waste Management & 660 & 324 & 229 & 151 & 62 & 3 & 4 & 6 & 14 \\
\hline SERVICES & 9.146 & 38.090 & 48.586 & 44.978 & 41.988 & 42.815 & 44.258 & 44.859 & 46.410 \\
\hline Construction & 1.257 & 5.899 & 7.265 & 6.782 & 6.006 & 5.713 & 5.545 & 5.992 & 7.473 \\
\hline Wholeshale and Retail Trade & 1.400 & 7.439 & 8.734 & 5.984 & 4.651 & 4.029 & 3.684 & 4.088 & 4.318 \\
\hline Transportation and Storage & 1.065 & 7.632 & 10.303 & 9.876 & 10.426 & 11.905 & 12.616 & 13.194 & 12.962 \\
\hline Accommodation and Food Service Activities & 375 & 2.800 & 3.230 & 2.992 & 2.438 & 2.013 & 1.990 & 2.781 & 2.658 \\
\hline Information and Communication Services & 2.915 & 6.898 & 6.858 & 6.578 & 6.463 & 7.061 & 7.802 & 5.837 & 5.597 \\
\hline Real Estate Activities & 210 & 2.996 & 3.963 & 4.189 & 4.490 & 4.483 & 4.533 & 4.743 & 4.591 \\
\hline Professional, Scientific and Technical Activities & 1.460 & 2.153 & 5.359 & 5.977 & 5.120 & 5.322 & 5.188 & 4.375 & 4.315 \\
\hline Administrative and Support Service Activities & 0 & 592 & 643 & 558 & 441 & 457 & 429 & 399 & 585 \\
\hline Public Admin. and Defence, Social Sec. & 0 & 0 & 0 & 0 & 0 & 0 & 0 & 0 & 0 \\
\hline Education & 51 & 171 & 125 & 102 & 83 & 80 & 123 & 178 & 257 \\
\hline Human Health and Social Work Activities & 150 & 736 & 896 & 780 & 770 & 685 & 658 & 679 & 800 \\
\hline Arts, Entertainment and Recreation & 71 & 525 & 496 & 396 & 262 & 173 & 166 & 163 & 227 \\
\hline Other Service Activities & 191 & 249 & 714 & 765 & 838 & 893 & 1.524 & 2.431 & 2.627 \\
\hline
\end{tabular}

Source: CBRT

\subsection{External Debt Indicators of Turkey and Selected Economies}

Various indicators suggested by the IMF and World Bank are mostly used to evaluate the foreign debt stance of an economy. Table 4.5 presents those and some other indicators for the analysis of the foreign debt position of the Turkish economy. The total external debt stock-GDP ratio is one commonly used indicator, and the level 
above 50 per cent is regarded as a sign of high-indebtedness of the economy. In the Turkish economy the ratio reached almost 60 per cent with the impact of the 2001 crisis and has never fallen under the 35 per cent level afterwards. It has been in an increasing trend since the 2008-2009 crisis, and as of end-2014 the ratio is just above the critical 50 per cent level.

The external debt-to-exports ratio above 275 per cent is thought to indicate high indebtedness, whereas the range between $165-275$ per cent denotes a moderately indebted economy. For the Turkish economy the ratio has been less than the 275 per cent level in the past ten years (Table 4.5). The decrease in the ratio has partly stemmed from the increase in exports except for the years of crises. Growth in the level of exports may imply an increase in the ability to meet foreign debt services; hence, the decline in this indicator can be taken positively. However, for the mentioned period the increase in the level of imports has been higher, leading to large trade deficits (Table 4.5). Although the level of exports as the ratio of GDP has increased to around 1819 per cent on average after the 2001 crisis, the net exports has not been performing well particularly since the mid-2000s. With the exception of 2009, the trade balance has registered an average of 8.3 per cent deficit since 2005 .

One other indicator regarding the sustainability of external debt is the debt service-to-exports ratio, implying the ability to meet debt service payments. A ratio between 18-30 per cent is considered to show moderate indebtedness of the economy, while a country with a ratio above 30 per cent is considered as highly indebted. The debt-to-exports ratio in Turkey was above 70 per cent during the 2001 crisis, fluctuated in the 2000s, after reaching 53,8 per cent in 2005 gradually declined and registered a level just above 30 per cent in 2014. Despite the decline, still almost one third of exports go towards debt service payments. Moreover, to evaluate the ratio and payment ability correctly, the rise in imports should be considered.

Table 4.6 reports some external debt indicators from the World Bank database for the Turkish economy and selected countries, i.e. the 'fragile five' with Argentina and Mexico. Among these seven economies, the Turkish economy has the highest external debt burden as share of national income and poorest figures for other indicators in the past decade. For instance, the debt service-GNI ratio shows that the economy transfers a high portion of its GNI (around 8,5 per cent on average) abroad through debt payments. South African and Argentine economies seem to have had some deterioration in the external debt indicators in the early 2000s, but made some progress in the second half of the decade, whereas the Turkish economy continues to have same issues. 


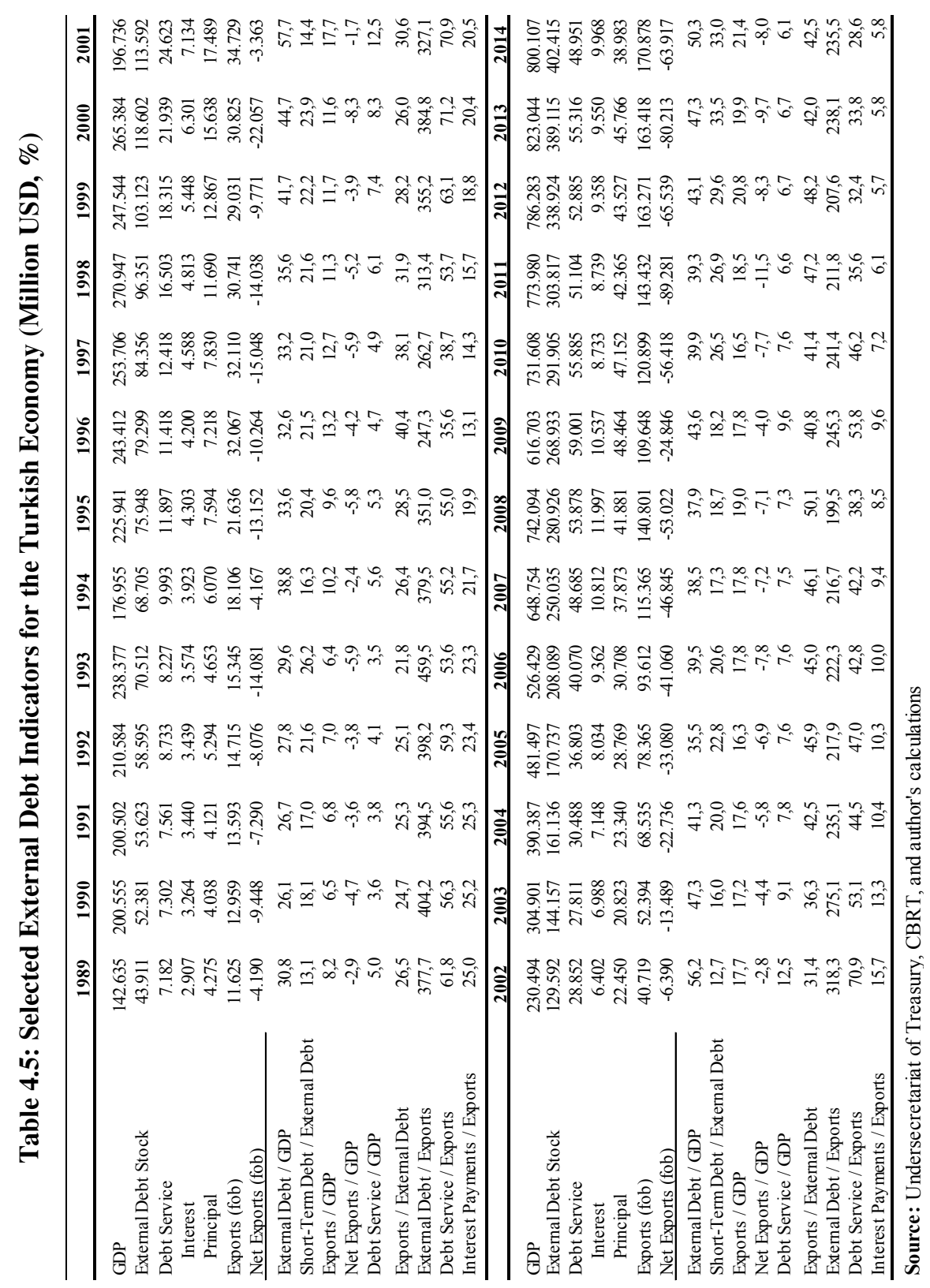


Table 4.6: External Debt Indicators for Selected Economies and Turkey

\begin{tabular}{|c|c|c|c|c|c|c|c|c|c|c|c|c|}
\hline & 2002 & 2003 & 2004 & 2005 & 2006 & 2007 & 2008 & 2009 & 2010 & 2011 & 2012 & 2013 \\
\hline \multicolumn{13}{|l|}{ Brazil } \\
\hline External debt stock (\% of GNI) & 47,7 & 44,1 & 34,3 & 22,0 & 18,3 & 17,8 & 16,3 & 17,7 & 16,7 & 16,6 & 19,9 & 21,9 \\
\hline External debt stock (\% of exports)* & 316,8 & 271,6 & 196,6 & 138,3 & 119,4 & 121,6 & 109,2 & 148,6 & 146,3 & 132,5 & 150,2 & 165,7 \\
\hline Total debt service ( $\%$ of exports)* & 71,1 & 67,2 & 47,9 & 46,2 & 38,2 & 28,1 & 23,5 & 23,5 & 19,0 & 19,4 & 15,5 & 28,6 \\
\hline Total debt service ( $\%$ of GNI) & 10,7 & 10,9 & 8,4 & 7,3 & 5,9 & 4,1 & 3,5 & 2,8 & 2,2 & 2,4 & 2,1 & 3,8 \\
\hline Short-term debt (\% of total reserves) & 61,8 & 49,9 & 47,7 & 44,6 & 23,7 & 21,8 & 18,9 & 16,7 & 22,7 & 12,0 & 8,7 & 9,3 \\
\hline Int. payments on ext. debt ( $\%$ of GNI) & 3,1 & 3,1 & 2,3 & 1,6 & 1,4 & 1,1 & 1,0 & 0,9 & 0,7 & 0,7 & 0,7 & 0,8 \\
\hline \multicolumn{13}{|l|}{ India } \\
\hline External debt stock (\% of GNI) & 20,3 & 19,4 & 17,3 & 14,6 & 16,9 & 16,5 & 18,7 & 18,9 & 17,3 & 18,1 & 21,5 & 23,0 \\
\hline External debt stock (\% of exports)* & 143,3 & 134,7 & 102,3 & 75,6 & 79,2 & 80,7 & 70,8 & 93,3 & 81,5 & 73,8 & 87,1 & 89,3 \\
\hline Total debt service ( $\%$ of exports)* & 20,9 & 29,2 & 14,5 & 14,9 & 8,6 & 15,6 & 9,7 & 6,0 & 6,8 & 6,4 & 6,8 & 8,6 \\
\hline Total debt service ( $\%$ of GNI) & 3,0 & 4,2 & 2,4 & 2,9 & 1,8 & 3,2 & 2,5 & 1,2 & 1,4 & 1,6 & 1,7 & 2,2 \\
\hline Short-term debt (\% of total reserves) & 5,7 & 6,1 & 5,2 & 6,4 & 14,1 & 13,0 & 17,0 & 16,4 & 18,8 & 26,1 & 31,1 & 31,1 \\
\hline Int. payments on ext. debt ( $\%$ of GNI) & 0,8 & 0,9 & 0,6 & 0,5 & 0,5 & 0,6 & 0,6 & 0,4 & 0,3 & 0,4 & 0,5 & 0,5 \\
\hline \multicolumn{13}{|l|}{ Indonesia } \\
\hline External debt stock (\% of GNI) & 74,3 & 59,3 & 56,1 & 52,1 & 39,0 & 35,7 & 32,1 & 34,5 & 28,8 & 26,7 & 28,9 & 30,8 \\
\hline External debt stock (\% of exports)* & 190,8 & 189,9 & 162,1 & 145,4 & 120,9 & 116,1 & 104,4 & 139,7 & 117,6 & 101,9 & 115,1 & 124,8 \\
\hline Total debt service ( $\%$ of exports)* & 25,1 & 26,2 & 24,2 & 20,8 & 25,2 & 18,8 & 14,1 & 19,4 & 17,4 & 14,4 & 16,8 & 19,4 \\
\hline Total debt service ( $\%$ of GNI) & 9,8 & 8,2 & 8,4 & 7,4 & 8,1 & 5,8 & 4,3 & 4,8 & 4,3 & 3,8 & 4,2 & 4,8 \\
\hline Short-term debt ( $\%$ of total reserves) & 55,0 & 53,7 & 60,7 & 31,7 & 28,7 & 32,8 & 39,7 & 36,4 & 34,3 & 34,7 & 39,2 & 47,7 \\
\hline Int. payments on ext. debt ( $\%$ of GNI) & 2,3 & 1,9 & 2,0 & 1,2 & 1,1 & 1,2 & 0,9 & 0,9 & 0,8 & 0,7 & 0,7 & 1,0 \\
\hline \multicolumn{13}{|l|}{ South Africa } \\
\hline External debt stock (\% of GNI) & 31,1 & 22,7 & 20,1 & 18,5 & 23,2 & 26,3 & 26,8 & 29,3 & 29,9 & 29,4 & 38,8 & 40,7 \\
\hline External debt stock (\% of exports)* & 86,6 & 74,3 & 70,4 & 62,0 & 70,6 & 75,0 & 67,4 & 98,6 & 98,6 & 90,1 & 120,3 & 120,7 \\
\hline Total debt service ( $\%$ of exports)* & 13,1 & 8,4 & 6,4 & 6,5 & 8,8 & 3,9 & 6,8 & 5,6 & 5,5 & 4,6 & 8,1 & 8,3 \\
\hline Total debt service ( $\%$ of GNI) & 4,5 & 2,5 & 1,7 & 1,8 & 2,8 & 1,3 & 2,6 & 1,6 & 1,6 & 1,5 & 2,5 & 2,7 \\
\hline Short-term debt ( $\%$ of total reserves) & 103,0 & 100,8 & 75,2 & 69,2 & 80,4 & 73,0 & 74,7 & 53,7 & 49,6 & 42,1 & 55,0 & 54,8 \\
\hline Int. payments on ext. debt ( $\%$ of GNI) & 1,2 & 0,8 & 0,6 & 0,7 & 1,0 & 0,9 & 1,0 & 0,9 & 0,9 & 0,9 & 1,2 & 1,2 \\
\hline \multicolumn{13}{|l|}{ Turkey } \\
\hline External debt stock ( $\%$ of GNI) & 56,8 & 47,9 & 40,9 & 36,1 & 40,0 & 40,4 & 40,0 & 45,7 & 41,3 & 39,8 & 43,1 & 47,9 \\
\hline External debt stock (\% of exports)* & 226,2 & 196,3 & 168,0 & 156,5 & 168,6 & 170,2 & 156,3 & 184,0 & 184,8 & 162,9 & 160,2 & 181,9 \\
\hline Total debt service ( $\%$ of exports)* & 48,5 & 38,7 & 34,5 & 37,4 & 32,9 & 32,4 & 30,2 & 41,6 & 36,6 & 30,1 & 26,3 & 28,9 \\
\hline Total debt service ( $\%$ of GNI) & 12,2 & 9,5 & 8,4 & 8,6 & 7,8 & 7,7 & 7,7 & 10,3 & 8,2 & 7,4 & 7,1 & 7,6 \\
\hline Short-term debt ( $\%$ of total reserves) & 57,9 & 64,7 & 82,7 & 74,1 & 67,7 & 56,4 & 71,3 & 65,4 & 90,0 & 93,1 & 84,4 & 98,5 \\
\hline Int. payments on ext. debt ( $\%$ of GNI) & 2,5 & 2,2 & 1,9 & 1,8 & 1,9 & 1,9 & 1,9 & 2,0 & 1,6 & 1,9 & 1,5 & 1,7 \\
\hline \multicolumn{13}{|l|}{ Argentina } \\
\hline External debt stock ( $\%$ of GNI) & 125,3 & 108,1 & 95,0 & 59,2 & 45,9 & 37,3 & 30,8 & 34,6 & 26,7 & 24,3 & 22,4 & 22,7 \\
\hline External debt stock ( $\%$ of exports)* & 452,5 & 429,2 & 380,2 & 250,3 & 198,1 & 166,2 & 140,4 & 182,5 & 143,2 & 129,3 & 136,2 & 137,7 \\
\hline Total debt service ( $\%$ of exports)* & 16,6 & 38,2 & 29,6 & 19,7 & 36,6 & 12,1 & 9,1 & 21,1 & 17,1 & 15,3 & 13,5 & 13,7 \\
\hline Total debt service ( $\%$ of GNI) & 5,6 & 11,8 & 7,4 & 4,7 & 8,5 & 2,7 & 2,0 & 4,0 & 3,2 & 2,9 & 2,2 & 2,3 \\
\hline Short-term debt ( $\%$ of total reserves) & 140,8 & 157,6 & 134,6 & 124,1 & 88,4 & 41,8 & 43,1 & 41,3 & 32,6 & 56,9 & 59,8 & 72,6 \\
\hline Int. payments on ext. debt ( $\%$ of GNI) & 1,8 & 1,4 & 1,4 & 1,4 & 1,6 & 1,1 & 0,8 & 0,9 & 0,8 & 0,7 & 0,6 & 0,6 \\
\hline \multicolumn{13}{|l|}{ Mexico } \\
\hline External debt stock (\% of GNI) & 21,9 & 23,4 & 22,3 & 20,7 & 18,3 & 19,5 & 19,1 & 22,8 & 25,1 & 26,2 & 32,2 & 35,9 \\
\hline External debt stock (\% of exports)* & 89,6 & 90,6 & 81,6 & 74,8 & 63,8 & 67,0 & 64,8 & 80,3 & 80,6 & 80,3 & 93,8 & 107,5 \\
\hline Total debt service (\% of exports)* & 21,1 & 17,8 & 19,1 & 15,5 & 20,1 & 12,8 & 11,1 & 12,7 & 10,4 & 11,4 & 17,9 & 10,3 \\
\hline Total debt service ( $\%$ of GNI) & 5,1 & 4,6 & 5,2 & 4,3 & 5,8 & 3,7 & 3,3 & 3,6 & 3,2 & 3,7 & 6,1 & 3,4 \\
\hline Short-term debt (\% of total reserves) & 47,2 & 38,8 & 31,6 & 30,0 & 34,4 & 31,4 & 29,2 & 29,7 & 47,6 & 44,7 & 55,8 & 59,8 \\
\hline Int. payments on ext. debt ( $\%$ of GNI) & 1,4 & 1,4 & 1,4 & 1,3 & 1,3 & 1,3 & 1,0 & 1,1 & 1,1 & 1,2 & 3,1 & 1,8 \\
\hline
\end{tabular}

Source: The World Bank, World Development Indicators

* 'of exports' refers as 'of exports of goods, services and primary income' 


\section{Conclusion}

Following the launch of the January 1980 Programme, the Turkish economy implemented an outward-looking, export-led economic model. The programme aimed for liberalisation of international trade along with liberalisation of financial markets. The new accumulation regime had significant implications for external debt dynamics of the economy.

In the 1990s the size and extent of the public domestic borrowing through high interest offering debt instruments became very critical, a process in which external borrowing accompanied domestic borrowing of the public sector. With the financial liberalisation, public sector made use of international financial resources directly or indirectly at an increasing rate. Public sector's domestic borrowing made contribution to the increase in private sector's foreign debt as private institutions borrowed from abroad at lower interest rates to lend the public sector domestically as well as to finance their production-related needs. Overall economic performance has become increasingly dependent on foreign resources which further contributed to the instability of the economy.

Throughout the period, while the total external debt of the Turkish economy has been on an increasing trend, the private sector's debt has presented a greater expansion. The external debt ratios, both total and private, had their peak during the 2001 crisis, and have never fallen to the pre-crisis levels. From the mid-2000s the external debt of the private sector exceeded the public sector's and reached distressing levels in the 2010s along with the private domestic indebtedness. Hence, both external and domestic debt stock of the private sector have caused serious concerns in the past few years.

Beside the size of the external debt, the use of external resources leads to distress as well. Previously, the debt was mostly used for speculative financial activities. On the other hand, external debt's use for imports of consumption goods as well as intermediate and capital goods has continued. The import-dependent production has been one of the factors behind the foreign debt growth. Furthermore, although the level of exports has been increasing, as the production of exported goods has also become dependent on imports, this increase does not help meet foreign debt service as it could do.

The 2008-2009 crisis led to further rise in external debt. The total foreign debt stock reached USD 402,4 billion in absolute terms and just above 50 per cent as share of GDP at the end of 2014. The private sector's external debt constitutes 70 per cent of the total, i.e. 35 per cent of GDP, or USD 282,3 billion in absolute terms, with a 40 per cent short-term debt.

A comparison between foreign debt accumulation and cumulative expansion in GDP gives some idea regarding the contribution of foreign debt to economic growth in the past few years. Total new debt accumulation between 2008 and 2014 was USD 121,5 billion, whereas total short-term debt accumulation was USD 80,4 billion. For the same period the change in GDP was USD 58,0 billion, a value which is even less than the total new short-term debt accumulation. 


\section{References:}

AKGÜL YILMAZ, Gülay and YILMAZ, Ahmet. Türkiye'de Borç Sarmalı ve Makro Ekonomik İstikrar, Istanbul, Arıkan Yayınları, 2007.

AKYÜZ, Yılmaz. "Financial System and Policies in Turkey in the 1980s," UNCTAD Working Papers, No.25, 1989.

AKYÜZ, Yılmaz and BORATAV, Korkut. "The Making of the Turkish Financial Crisis", World Development, 31(9), 2003, pp.1549-1566.

ALPER, C. Emre. "The Turkish Liquidity Crisis of 2000: What Went Wrong," Russian and East European Finance and Trade, 37(6), 2001, pp.51-71.

BAYSAN, Tercan and BLITZER, Charles. “Turkey's Trade Liberalisation in the 1980s and Prospects for its Sustainability," in Tosun Arıcanli and Dani Rodrik (eds), The Political Economy of Turkey: Debt, Adjustment and Sustainability, London, Macmillan, 1990, pp.9-36.

BORATAV, Korkut. Bir Krizin Kısa Tarihi. Ankara, Arkadas Yayincilik, 2009.

CBRT (Central Bank of the Republic of Turkey). Statistical Data, at http://www.tcmb. gov.tr/wps/wcm/connect/TCMB+EN/TCMB+EN/Main+Menu/STATISTICS

ERTUĞRUL, Ahmet and SELÇUK, Faruk. "A Brief Account of the Turkish Economy: 1980-2000," Russian and East European Finance and Trade, 37(6), 2002, pp.1-29.

EPSTEIN, Gerald A. (2005) (ed.) Financialization and the World Economy. Cheltenham, Massachusetts: Edward Elgar, 2005.

FOSTER, John Bellamy. “The Financialization of Capitalism”, Monthly Review, 58(11), 2007.

GOLDSTEIN, Jonathan P. “Introduction: The Political Economy of Financialization”, Review of Radical Political Economics, 41(4), 2009, pp.453-457.

GRABLE, Ilene. "Speculation-Led Economic Development: A Post-Keynesian Interpretation of Financial Liberalization Programmes in The Third World", International Review of Applied Economics, 9(2), 1995, pp.127-149.

ISSA (Independent Social Scientists Alliance). "Turkey in 2005 and Beyond: Macroeconomic Policy, Patterns of Growth and Persistent Fragilities," mimeo, 2005, at http://www.globalpolicynetwork.org//data/turkey/turkey-analysis.pdf

KRIPPNER, Greta. “The Financialization of the American Economy”, Socio-Economic Review, 3, 2005, pp.173-208.

MCKINNON, Ronald I. Money and Capital in Economic Development, Washington, D.C., The Brookings Institution, 1973.

ÖNDER, Izzettin. "Financial Liberalisation in Turkey," Seijo University Economics Papers, No.136, 1998.

ÖZATAY, Fatih. "The lessons of the 1994 Crisis in Turkey: Public Debt (Mis)Ma- 
nagement and Confidence Crisis," Yapı Kredi Economic Review, 7, 1997, pp.21-38.

PALLEY, Thomas I. "Financialization: What It Is and Why It Matters", The Levy Economics Institute Working Paper, No.525, 2007.

SHAW, Edward S. Financial Deepening in Economic Development, New York, Oxford University Press, 1973.

SÖNMEZ, Sinan. “Türk İktisat Politikalarındaki 'Çıpa': Dış Borçlanma”, in Ahmet Haşim Köse et.al. (eds), İktisadi Kalkınma, Kriz ve İstikrar: Oktar Türel’e Armağan, İstanbul, İletişim Yayınları, 2003, pp.305-361.

Turkish Statistical Institute (TurkStat), Statistics, at http://www.turkstat.gov.tr/Start. do

Undersecretariat of Treasury of the Republic of Turkey, Statistics, at http://www.treasury.gov.tr/Link/treasury-statistics

UYGUR, Ercan. "Liberalisation and Economic Performance in Turkey", UNCTAD Working Papers, No.65, 1993.

World Bank, World Development Indicators, at http://data.worldbank.org/data-cata$\log$ /world-development-indicators

YELDAN, Erinç. "Financial Liberalization and Financial Repression in Turkey: Policy Analysis in a CGE Model with Financial Markets", Journal of Policy Modeling, 19(1), 1997, pp.79-117.

YELDAN, Erinç. "On the IMF-Directed Disinflation Programme in Turkey: A Program for Stabilisation and Austerity or A Recipe for Impoverishment and Financial Chaos?" in Neşecan Balkan (ed) The Ravages of Neo-Liberalism: Economy, Society and Gender in Turkey, New York, Nova Science Publications, 2002, pp.1-28.

YÜLEK, Murat. Financial Liberalization and the Real Economy: The Turkish Experience, Ankara, Capital Markets Board of Turkey, 1998. 